\title{
Cripto-1 Ablation Disrupts Alveolar Development in the Mouse Mammary Gland through a Progesterone Receptor-Mediated Pathway
}

\author{
Malgorzata Klauzinska, ${ }^{*}$ David McCurdy, ${ }^{\dagger}$ Maria Cristina Rangel, ${ }^{*}$ Arun Vaidyanath, ${ }^{\dagger}$ Nadia P. Castro, ${ }^{*}$ Michael M. Shen, \\ Monica Gonzales, ${ }^{*}$ Daniel Bertolette, ${ }^{*}$ Caterina Bianco, ${ }^{*}$ Robert Callahan, ${ }^{\dagger}$ David S. Salomon, ${ }^{*}$ and Ahmed Raafat ${ }^{\dagger}$
}

\begin{abstract}
From the Mouse Cancer Genetics Program, * National Cancer Institute, National Institutes of Health, Frederick, Maryland; the Basic Research Laboratory, National Cancer Institute, National Institutes of Health, Bethesda, Maryland; and the Departments of Medicine Genetics and Development, Urology, and Systems Biology, ${ }^{\ddagger}$ Columbia University Medical Center, New York, New York
\end{abstract}

\author{
Accepted for publication \\ July 28, 2015 \\ Address correspondence to \\ Ahmed Raafat, Ph.D., Basic \\ Research Laboratory, National \\ Cancer Institute, National \\ Institutes of Health, 37 Convent \\ Dr, Bldg 37, Room 1118, \\ Bethesda, MD 20892. E-mail: \\ raafata@mail.nih.gov.
}

\begin{abstract}
Cripto-1, a member of the epidermal growth factor-Cripto-1/FRL-1/Cryptic family, is critical for early embryonic development. Together with its ligand Nodal, Cripto-1 has been found to be associated with the undifferentiated status of mouse and human embryonic stem cells. Several studies have clearly shown that Cripto- 1 is involved in regulating branching morphogenesis and epithelialmesenchymal transition of the mammary gland both in vitro and in vivo and together with the cofactor GRP78 is critical for the maintenance of mammary stem cells ex vivo. Our previous studies showed that mammary-specific overexpression of human Cripto-1 exhibited dramatic morphological alterations in nulliparous mice mammary glands. The present study shows a novel mechanism for Cripto-1 regulation of mammary gland development through direct effects on progesterone receptor expression and pathways regulated by progesterone in the mammary gland. We demonstrate a strict temporal regulation of mouse Cripto-1 (mCripto-1) expression that occurs during mammary gland development and a stage-specific function of mCripto-1 signaling during mammary gland development. Our data suggest that Cripto-1, like the progesterone receptor, is not required for the initial ductal growth but is essential for subsequent side branching and alveologenesis during the initial stages of pregnancy. Dissection of the mechanism by which this occurs indicates that mCripto-1 activates receptor activator NF- $\kappa \mathrm{B} /$ receptor activator NF- $\kappa \mathrm{B}$ ligand, and NF- $\kappa \mathrm{B}$ signaling pathways. (Am J Pathol 2015, 185: 2907-2922; http://dx.doi.org/10.1016/j.ajpath.2015.07.023)
\end{abstract}

Cripto-1/teratocarcinoma-derived growth factor-1 is the original member of the epidermal growth factor (EGF)Cripto-1/FRL-1/Cryptic family of vertebrate signaling molecules. ${ }^{1}$ During embryogenesis, Cripto-1 functions primarily as a coreceptor for the transforming growth factor- $\beta$ family ligands Nodal and growth and differentiation factors 1 and 3 , leading to the activation of type I (Alk4/Alk7) serine-threonine kinase receptors and the activin type II receptor complex. This signaling pathway triggers both the phosphorylation and activation of the Smad-2/Smad-3. In addition to functioning as a coreceptor for Nodal, Cripto-1 can also function as a ligand for glypican-1, activating the c-Src/mitogen-activated protein kinase and phosphatidylinositol 3-kinase/protein kinase B
(Akt) signaling pathways that regulate cell proliferation, motility, and survival. ${ }^{1,2}$

During mouse embryonic development, Cripto-1 is initially expressed in the epiblast before gastrulation. During gastrulation, Cripto-1 is highly expressed in the primitive streak, migrating mesoderm, and the node and axial mesoderm. ${ }^{3,4}$ In adults, Cripto-1 expression is significantly reduced and is probably sequestered to the stem cell compartment of adult tissues. ${ }^{5}$ In fact, Cripto- 1 is an established regulator of embryonic stem cells and induced

\footnotetext{
Supported by Intramural Research Program of the NIH, National Cancer Institute (Bethesda, MD).
}

Disclosures: None declared. 
pluripotent stem cells ${ }^{6,7}$ and together with Nanog, Oct4, and Sox2, Cripto-1 has been recognized as a potential stem cell marker. ${ }^{5}$ Recently, Cripto-1, together with the coreceptor GRP78, was shown to have an essential role in the maintenance of dormant hematopoietic stem cells in the bone marrow osteoclast niche under hypoxia by regulating the hypoxia-inducible factor- 1 complex $^{8}$ and in the maintenance in a paracrine manner of mammary stem cells ex vivo. ${ }^{9}$

Analysis of the temporal expression of Cripto-1 in the developing mammary gland demonstrated that Cripto-1 is expressed during embryonic and postnatal mammary gland development. $^{9-11}$ In the mouse embryo, Cripto- 1 can be detected in the mesenchyme surrounding the mammary placodes but not in the epithelial placodes, similar to Msx2, Lef- 1 , and $\beta$-catenin in the Wnt pathway, suggesting that Cripto-1 might be important for mammary mesenchymal development. Postnatally, Cripto-1 can be detected at low levels in ductal epithelial cells of the nulliparous mouse mammary gland and its expression significantly increases during pregnancy and lactation. ${ }^{11}$

Several studies have clearly shown that Cripto-1 is involved in regulating branching morphogenesis and epithelial-mesenchymal transition of the mammary gland both in vitro and in vivo. ${ }^{1}$ Kenney et $\mathrm{al}^{12}$ first demonstrated that recombinant Cripto-1, when incorporated into Elvax slow-release implants and inserted into the mammary gland of nulliparous mice, promoted a de novo network of branching ducts migrating toward the pellet. These dramatic changes in cell morphological characteristics are also observed in vitro. Overexpression of Cripto-1 in EpH4 mouse mammary epithelial cells induces the extensive formation of branching, duct-like structures that contain a lumen when grown in a three-dimensional collagen type I matrix. ${ }^{13}$

Previously, our group showed that mammary-specific overexpression in nulliparous transgenic female mice using a human Cripto-1 transgene under the transcriptional control of the mouse mammary tumor virus (MMTV) promoter (MMTV-hCripto-1) exhibited a dramatic morphological alteration in nulliparous virgin mammary glands, specifically displaying a significant increase in lateral secondary and tertiary side branching. ${ }^{10}$ On the other hand, nulliparous transgenic female mice expressing the human Cripto-1 transgene in the mammary gland under the transcriptional control of the whey acidic protein (WAP; official symbol WFDC1) promoter results in delayed lobulo-alveolar development during late pregnancy and early lactation as well as accelerated apoptosis during early involution. Notably, we also observed an increased rate of proliferation resulting in the induction of mammary hyperplasias and the development of mammary tumors containing different histological subtypes, as was observed in MMTV-Cripto-1 mice. ${ }^{14}$ Involvement of Cripto-1 in mammary gland development has been validated in two gain-of-function human Cripto-1 transgenic mouse strains where overexpression of the Cripto- 1 transgene in the mammary gland produces a distinct phenotype in virgin and pregnant mice with accelerated and increased ductal side branching and impaired alveolar development. However, the molecular mechanism by which endogenous mouse Cripto-1 (mCripto-1) might regulate mammary gland development remains unknown.

To further investigate the role of Cripto- 1 in normal mammary gland development, we generated several conditional knockout (KO) FVB/N transgenic mouse strains in which mammary gland expression of the mCripto- 1 gene (official name $C f c 1$ ) was deleted with Cre recombinase expression either early in perinatal mice using the MMTV promoter or late using the WAP promoter that is maximally expressed during late pregnancy and lactation.

\section{Materials and Methods}

\section{Mouse Breeding, Genotyping, Quantitative PCR, and Body Weight of Pups}

The Cripto ${ }^{f l o x}$ mice have a mixed background and were previously described and characterized. ${ }^{4}$ We backcrossed these mice with $\mathrm{FVB} / \mathrm{N}$ mice for at least six generations to change the mixed background to the FVB/N background. The WAP-Cre ${ }^{+} /$Cripto $^{\text {flox }}$ (WAP-CRKO) and MMTV$\mathrm{Cre}^{+} / \mathrm{Cripto}^{\text {fox }}$ (MMTV-CRKO) mice were generated by crossing the Cripto $^{\text {flox }}$ mice with the WAP-Cre ${ }^{15}$ and MMTV-Cre $e^{16,17}$ mice, respectively. Mice tail DNA were genotyped by PCR analysis with specific primers that generate a 300-bp DNA band for WAP-Cre, a 350-bp DNA band for MMTV-Cre, a 400-bp band for Cripto ${ }^{\text {flox }}$, and a 240-bp fragment for the wild-type (WT) mCripto-1. Primer sequences are shown in Table 1.

Activation of the Cre-recombinase in the WAP-CRKO and MMTV-CRKO mice deletes exons, 3, 4, and 5 of the Cripto $^{\text {flox }}$ gene. Quantitative RT-PCR (RT-qPCR) analysis of RNA extracted from mammary tissue of pregnant $\mathrm{FVB} / \mathrm{N}$, WAP-CRKO, and MMTV-CRKO mice was performed using SYBR Green PCR master mix. The sequences of the RT-qPCR primers are listed in Table 2. Copy number calculation was performed as described previously. ${ }^{18}$ In brief, for each gene, a standard curve was generated using a specific cDNA clone containing the region to be amplified. Standard curve slope and amplification plots were analyzed using MxPro PCR software version 4.10 (Stratagene, Santa Clara, CA). The relative abundance of mammary gland target mRNA was calculated as the ratio of the copy number of target mRNA normalized/the copy number of glyceraldehyde-3-phosphate dehydrogenase mRNA, a housekeeping gene in mammary tissue.

Pup body weight measurements were taken every 72 hours starting at day 3 postpartum and continued for 18 days. Litter size was restricted to six pups born to primiparous female mice. Mice had access to water and food ad libitum during the experiment and lived in a 12-hour dark/ light cycle. The National Cancer Institute Animal Care and Use Committee (Bethesda, MD) approved all experimental procedures. 
Table 1 Primer Sequences Used for PCR Genotyping

\begin{tabular}{llll}
\hline Primer name & Forward primer & Reverse primer & Product (nt) \\
\hline Cripto $^{\text {flox }}$ & $5^{\prime}$-ATGCTGGGTCCTTAGGGAAT-3' & $5^{\prime}$-GGGTCATCCTCTCCTAGCC-3' & 400 \\
Cripto WT $^{\prime}$ & $5^{\prime}$-ATGCTGGGTCCTTAGGGAAT-3' & $5^{\prime}$-GGGTCATCCTCTCCTAGCC-3' \\
WAP-Cre & $5^{\prime}$-CATCACTCGTTGCATCGACCGG-3' & $5^{\prime}$-TAGAGCTGTGCCAGCCTCTTCC-3' & 300 \\
MMTV-Cre & $5^{\prime}$-GGTTCTGATCTGAGCTCTGAGTG-3' & $5^{\prime}$-CATCACTCGTTGCATCGACCGG-3' & 350 \\
\hline
\end{tabular}

nt, nucleotides; WAP, whey acidic protein; WT, wild type.

\section{Mammary Morphology, Histology, and Epithelial Content Analysis}

Representative mammary tissue specimens were collected from female mice of FVB/N, WAP-CRKO, and MMTVCRKO at key developmental stages: 10-week-old (nulliparous adults), early pregnant (6 days pregnant), late pregnant (15 days pregnant), early lactation (1 day lactation), and early involution (3 days involution). Mammary whole mounts were prepared from the fourth abdominal gland, as previously described. ${ }^{19}$ Briefly, mammary glands were fixed in freshly prepared $4 \%$ paraformaldehyde in phosphate-buffered saline $(\mathrm{pH}$ 7.4) for 2 hours, rinsed through several changes of phosphate-buffered saline buffer, dehydrated in ethanol, and stained and examined grossly under a dissecting microscope, or embedded in paraffin blocks. For histology analysis, paraffin sections ( $5 \mu \mathrm{m}$ thick) were placed on slides, deparaffinized, and stained with hematoxylin and eosin. Epithelial content quantification was performed using whole mounts and an AxioVision digital image processing software analysis system version 4.4 (Zeiss, Oberkochen, Germany). The quantification is based on surface area of the whole mount occupied by the mammary epithelial structures. This technique is well known and has been used in numerous studies. ${ }^{19}$

\section{IHC, Apoptosis, and Western Blot Analysis}

Immunohistochemical (IHC) analysis of paraffin-embedded sections was performed using the avidin-biotin complex method, according to the manufacturer's recommendations (Vector Laboratories Inc., Burlingame, CA), as described previously. ${ }^{20}$ Primary antibody incubation was performed overnight at $4^{\circ} \mathrm{C}$ : proliferating cell nuclear antigen (sc-9857; Santa Cruz Biotechnology, Santa Cruz, CA; diluted 200×), progesterone receptor (PR; A-0098; Dako, Carpinteria, CA; diluted 150×), cyclin D1 (2879; Cell Signaling Technology Inc., Beverly, MA; diluted 100×), and p-p65 (sc-33020; Santa Cruz Biotechnology; diluted $100 \times$ ). For immunofluorescence analysis, after incubation with receptor activator for NF- $\kappa$ B ligand (RANKL; AF462; R\&D Systems, Minneapolis, MN; diluted $2000 \times$ ) or RANK (AF692; R\&D Systems; diluted $2500 \times$ ) primary antibody, samples were washed twice with phosphate-buffered saline and stained with the fluorochrome-coupled secondary antibodies. Samples were mounted for microscopic inspection in mounting medium (DAPI; Vector Laboratories, Burlingame, CA). To reduce variability because of fluorescence fading, images were captured and stored within 24 hours after the end of the experiment. For apoptosis, the Roche in situ cell death detection kit, POD (1684817; Roche, Indianapolis, IN) was used, according to the manufacturer's recommendations. The labeling index was determined in at least a total of 3000 cells in each experiment. Western blot analysis was conducted, as previously described. ${ }^{21}$

\section{Luciferase Reporter Assays}

Dual-luciferase assays were performed using the DualLuciferase Assay system from Promega (Madison, WI). The effect of progesterone on expression of firefly luciferase driven by the mCripto- 1 promoter and the effect of recombinant Cripto-1 protein on expression of firefly luciferase driven by the NF- $\kappa \mathrm{B}$ promoter (Promega; catalog number E8491) were investigated using PR-positive T47D human breast cancer cells or NOG-8 mouse mammary epithelial cells, respectively. The pRLTK (Renilla luciferase) was cotransfected as an internal control. Luciferase values were corrected for transfection efficiency by dividing luciferase light units by Renilla light units (expressed as relative luciferase units). The effect of Cripto-1 on

Table 2 Primer Sequences Used for Quantitative RT-PCR

\begin{tabular}{|c|c|c|}
\hline Gene name & Forward primer & Reverse primer \\
\hline Cripto-1 & 5'-TGTTCGCAAAGAGCACTGTGG-3' & $5^{\prime}-\mathrm{TGAGGTCCTGGTCCATCACTTGAC-3^{ \prime }}$ \\
\hline Csn2 & 5'-GCTCAGGCTCAAACCATCTC-3' & $5^{\prime}-$ TGTGGAAGGAAGGGTGCTAC-3' \\
\hline PR (Pgr) & 5'-GGTCCCCCTTGCTTGCA-3' & $5^{\prime}$-CAGGACCGAGGAAAAAGCAG-3' \\
\hline RANKL (Tnfsf11) & $5^{\prime}-$ CCAGCATCAAAATCCCAAGTT-3' & $5^{\prime}-$ TCAAGGTTCTCAGTGGCACAT-3' \\
\hline RANK (Tnfrsf11a) & $5^{\prime}-$ CGAGGAAGATTCCCACAGAG- $3^{\prime}$ & $5^{\prime}$-CAGTGAAGTCACAGCCCTCA-3' \\
\hline
\end{tabular}

$\mathrm{PR}$, progesterone receptor; RANKL, receptor activator for NF- $\kappa B$ ligand; WAP, whey acidic protein. 
expression of gaussian luciferase driven by the mouse PR promoter (custom-made $1.5-\mathrm{kb}$ promoter of mouse PR; GeneCopoeia, Rockville, MD) was investigated using 293T cells. Cripto-1 was introduced in a vector A6E. pFFLK (firefly luciferase) was cotransfected as an internal control. For all experiments, three cell samples were transfected and processed independently. Experiments were repeated at least three times. Differences were considered statistically significant at $P<0.05$.

\section{Hormone Treatment}

Nulliparous BALB/c mice were treated with progesterone to examine its effect on Cripto-1 expression. Intact female mice at 9 weeks of age were treated with $1 \mathrm{mg}$ progesterone administered twice daily for 5 days as s.c. injections in 0.25-mL saline excipient.

\section{Statistical Analysis}

Quantitative values are represented as the means \pm SEM of at least three experiments. All in vivo experiments were repeated at least three times, and at least five mice were used in each experiment. Data were analyzed for significance using $t$-test or analysis of variance, as appropriate. $P<0.05$ was considered significant.

\section{Results}

\section{Conditional Deletion of mCripto-1 in the Mammary Gland}

To determine the consequences of early or late deletion of mCripto-1 on normal mammary development, we conditionally deleted exons 3,4 , and 5 of the mCripto- 1 gene using the mammary gland epithelium-specific MMTV-Cre or WAP-Cre transgenes. ${ }^{15-17}$ Expression of the MMTV-Cre and WAP-Cre transgenes is limited to epithelial cells in the mammary gland and is not expressed in the mammary stroma. ${ }^{15,17,22}$ MMTV is active in the mammary epithelium at early stages of mammary gland development in nulliparous mice, ${ }^{17}$ whereas WAP is active during late pregnancy and lactation. ${ }^{23}$ Thus, using these two Cre expression systems allows the early and late deletion of the Flox target gene. DNA sequence analysis of $m$ Cripto- 1 in $m$ Cripto $^{\text {flox }}$ mice showed insertion of a 162 nucleotide (nt) that contains a LOX P site within intron 5 (Supplemental Figure S1). We took advantage of the Cre expression system to identify the experimental mice. Primers used in tail DNA genotyping flank the mentioned $162 \mathrm{nt}$. Primer sequence and PCR product size are shown in Table 1 and Figure $1 \mathrm{~A}$.

RT-qPCR analysis of total mammary gland RNA showed that only mammary glands of FVB/N mice have the WT $m$ Cripto-1 gene, whereas it is deleted in WAP-CRKO and MMTV-CRKO mice (Figure 1B), confirming the deletion of
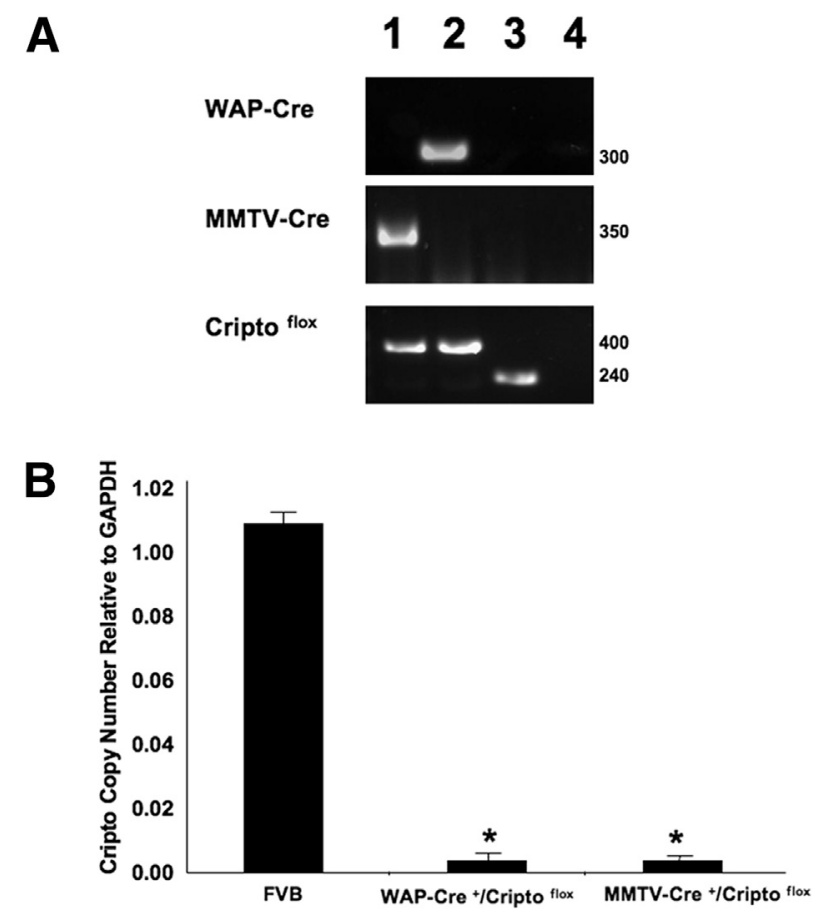

Figure 1 Genotyping and analysis of Cripto expression in MMTV-Cre ${ }^{+} /$ Cripto $^{\text {flox }}$ (MMTV-CRKO) and whey acidic protein-Cre ${ }^{+} /$Cripto $^{\text {flox }}$ (WAP-CRKO) mammary glands. Cripto ${ }^{\text {flox }}$ mice were genetically crossed with MMTV-Cre or WAP-Cre mice to generate MMTV-CRKO mice or WAP-CRKO, as described in Materials and Methods. A: PCR tail DNA analysis of MMTV-CRKO (lane 1), WAP-CRKO (lane 2), FVB/N (lane 3), and negative control (lane 4). B: Quantitative RT-PCR (RT-qPCR) analysis of total RNA extracted from WAPCRKO, MMTV-CRKO, and FVB/N mammary glands from pregnant mice. Total RNA was extracted from two separate pools (four mice each) of the number 4 inguinal mammary glands of primiparous female mice and used in RTqPCR, as described in Materials and Methods. Cripto-1 expression is barely detectable in the mammary glands of MMTV-CRKO and WAP-CRKO mice reflecting the deletion of exons 3, 4, and 5 in these mice. Each bar represents the ratio of specific mRNA copy number normalized to glyceraldehyde-3-phosphate dehydrogenase (Gapdh) mRNA levels. Error bars represent SEM (B). ${ }^{*} P<0.05$.

exons 3, 4, and 5. We also performed Western blot and IHC analysis of Cripto-1 for FVB/N and both Cripto-1 KO (data not shown). Currently available antibodies against Cripto-1 do not discriminate between mCripto-1 and Cripto-3; therefore, the observed Western blot data were not clear.

\section{Mammary Gland Development and Proliferation in mCripto-1 KO Mice}

Mammary glands from 10-week-old nulliparous WAPCRKO or MMTV-CRKO mice exhibited normal ductal elongation and branching, which was similar to mammary glands from comparably staged WT FVB/N mice (Figures 2, $\mathrm{A}, \mathrm{F}$, and $\mathrm{K}$, and $3, \mathrm{~A}, \mathrm{~F}$, and $\mathrm{K}$ ). Both WAP-CRKO and MMTV-CRKO mice were able to lactate and nurse their pups. Morphological (Figure 2) and histological (Figure 3) analysis of mammary glands showed a significant reduction of branching during early pregnancy (Figures 2, B, G, and L, and $3, \mathrm{~B}, \mathrm{G}$, and L) in the WAP-CRKO and MMTV-CRKO 


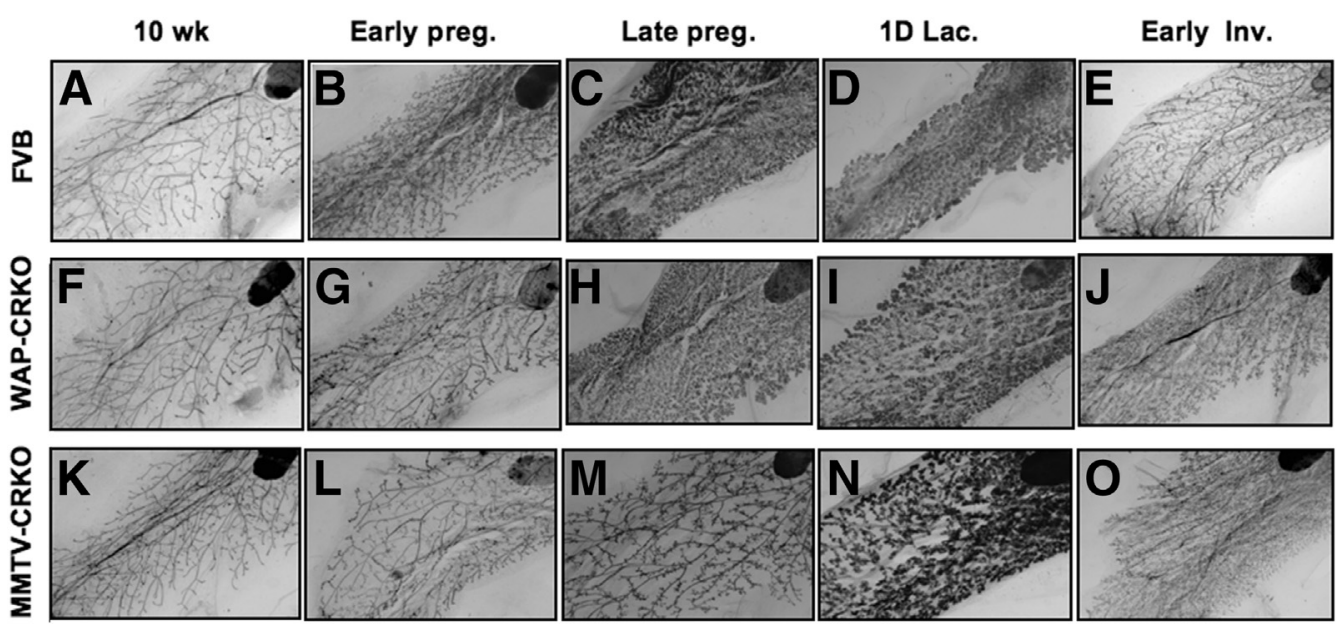

Figure 2 Morphology of the mammary glands from FVB/N, whey acidic protein-Cre ${ }^{+} /$Cripto $^{\text {flox }}$ (WAP-CRKO), and MMTV-Cre C $^{+}$Cripto $^{\text {flox }}$ (MMTV-CRKO) mice. Whole mounts of mammary glands from FVB/N $(\mathbf{A}-\mathbf{E})$, WAP-CRKO $(\mathbf{F}-\mathbf{J})$, and MMTV-CRKO $(\mathbf{K}-\mathbf{0})$ mice were collected at the indicated developmental stages and processed, as described in Materials and Methods: 10-week-old nulliparous females (10 wk), 6 days pregnancy (Early preg.), 15 days pregnancy (Late preg.), 1 day lactation (1D lac.), and 3 days involution (Early Inv.). $n=8$ mice per developmental stage (A-0). Original magnification, $\times 20(\mathbf{A}-\mathbf{0})$.

mice. In late pregnancy, alveolar development in the WAP-CRKO and MMTV-CRKO mice was also significantly reduced compared with $\mathrm{FVB} / \mathrm{N}$ mice (Figures 2, C, H, and $\mathrm{M}$, and $3, \mathrm{C}, \mathrm{H}$, and $\mathrm{M}$ ). In lactating mammary glands alveolar reduction was more significant in the MMTV-CRKO mice than in the WAP-CRKO mice (Figures 2, D, I, and N, and $3, \mathrm{D}, \mathrm{I}$, and $\mathrm{N}$ ). In addition, mammary gland involution was delayed in the CRKO mice in comparison to the FVB/N mice (Figures 2, E, J, and O, and 3, E, J, and O), with the MMTVCRKO showing the most delayed involution (Figures 2, E, J, and $\mathrm{O}$, and $3, \mathrm{E}, \mathrm{J}$, and $\mathrm{O}$ ).

Mammary epithelial content of the 10-week-old nulliparous WAP-CRKO and MMTV-CRKO mice was comparable to the mammary glands of FVB/N mice (Figure 4). However, it was significantly lower than the epithelial content of the FVB/N mice during pregnancy and lactation (Figure 4). In the early involuting mammary gland, there was a small but significant increase in the epithelial content in the WAP-CRKO and MMTV-CRKO mice compared with the FVB/N mice (Figure 4), which reflects the delayed involution phenotype observed in the experimental mammary glands (Figures 2, E, J, and $\mathrm{O}$, and $3, \mathrm{E}$, J, and $\mathrm{O}$ ).

In the mammary gland, the increase in ductal side branching and development of lobulo-alveolar structures during pregnancy result from the expansion and proliferation of ductal and alveolar progenitor epithelial cells. ${ }^{24}$ mCripto-1-deficient mice show rudimentary alveolar development and form the initial alveolar buds, suggesting that mCripto-1 expression does not initiate lobular differentiation. Rather, loss of mCripto-1 impairs epithelial cell proliferation. To address this issue and to investigate the effects of mCripto-1 deletion on mammary gland
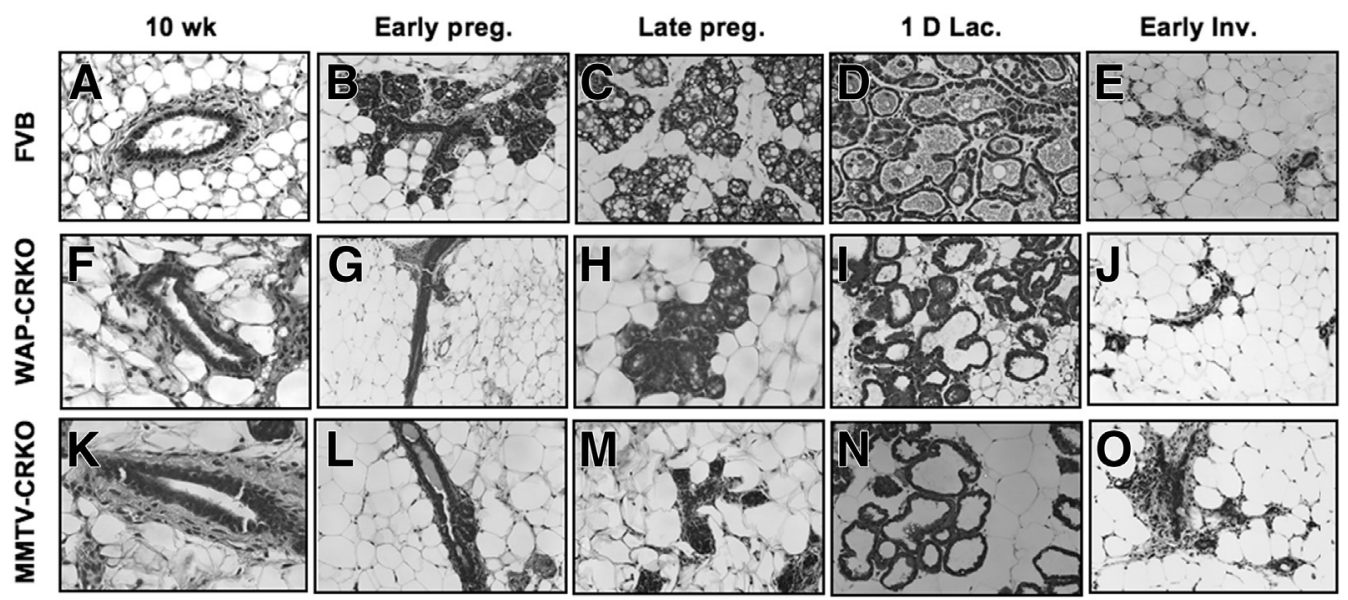

Figure 3 Histology of the mammary glands from FVB/N, whey acidic protein-Cre + Cripto flox (WAP-CRKO), and MMTV-Cre ${ }^{+} /$Cripto $^{\text {flox }}$ (MMTV-CRKO) mice. Mammary gland tissue was collected at the indicated developmental stages and processed, as described in Materials and Methods: 10-week-old nulliparous females (10 wk), 6 days pregnancy (Early preg.), 15 days pregnancy (Late preg.), one day lactation (1D lac.), and 3 days involution (Early Inv.). Histological analysis shows impaired side branching and alveolar development in the MMTV-CRKO mice (K-0) and WAP-CRKO (F- J) mammary glands versus FVB/N mice $(\mathbf{A}-\mathbf{E}) . n=8$ mice per developmental stage $(\mathbf{A}-\mathbf{0})$. Original magnification, $\times 40(\mathbf{A}-\mathbf{0})$. 


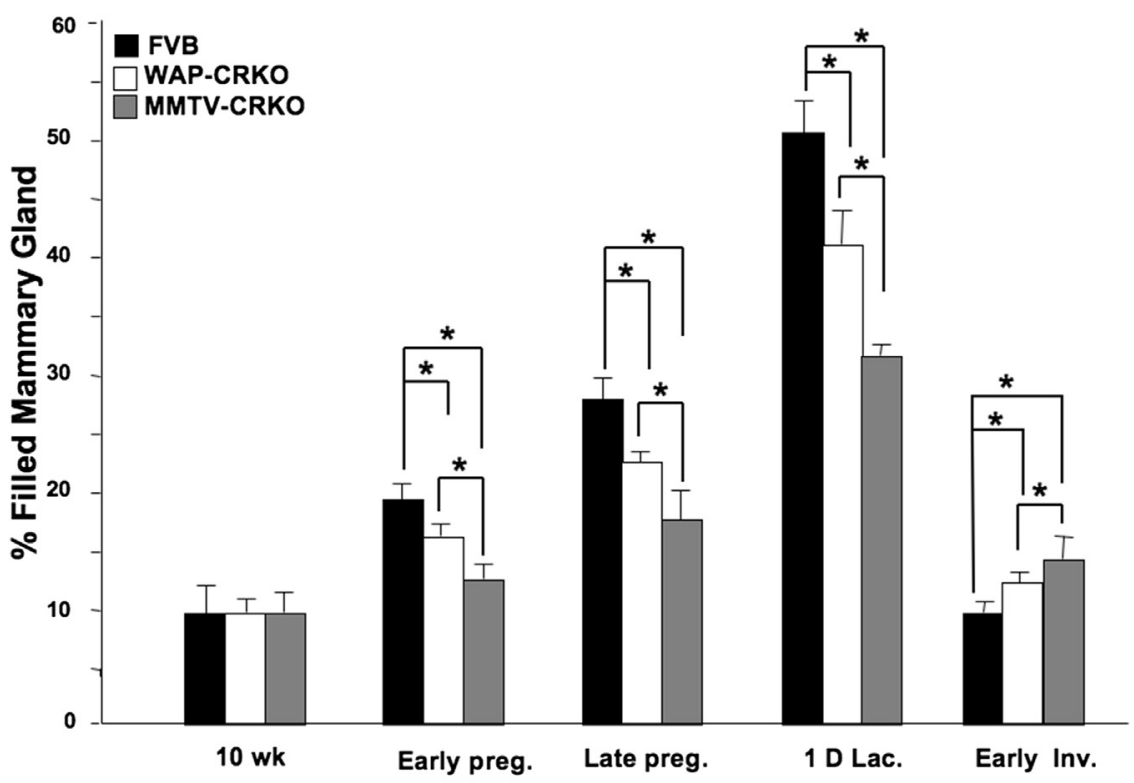

Figure 4 Epithelial content of the mammary glands from $\mathrm{FVB} / \mathrm{N}$, whey acidic protein- $-\mathrm{Cre}^{+} /$ Cripto $^{\text {flox }}$ (WAP-CRKO), and MMTV-Cre ${ }^{+} /$Cripto $^{\text {flox }}$ (MMTV-CRKO) mice. The quantification of epithelial content of mammary glands was conducted on the whole mounts as described in Materials and Methods. Mice were euthanized at the indicated developmental stage [10-week-old nulliparous females (10 wk), 6 days pregnancy (Early preg.), 15 days pregnancy (Late preg.), one day lactation (1D lac.), and 3 days involution (Early Inv.)], and the fourth inguinal mammary glands were collected and fixed as described in Materials and Methods. $\mathrm{FVB} / \mathrm{N}$ mice have the highest epithelial content, followed by the WAP-CRKO and MMTV-CRKO mice. In the involuting mammary glands, CRKO experimental mice have significantly higher epithelial content than the involuting mammary glands from $\mathrm{FVB} / \mathrm{N}$. A total of at least five to six mice were used for each experiment. ${ }^{*} P<0.05$.

\section{Developmental Stage}

morphology and epithelial cell density, we assessed mammary epithelial proliferation (Figure 5). Cell proliferation was comparable in the mammary glands of $\mathrm{FVB} / \mathrm{N}$ and experimental mCripto-1 KO 10-week-old nulliparous mice. However, it was significantly lower in the mCripto-1deficient mice $(P<0.05)$ than in the $\mathrm{FVB} / \mathrm{N}$ control mice during early (6 days) and late (15 days) pregnancy (Figure 5). In contrast, cell proliferation was significantly higher $(P<0.05)$ in the 3-day involuting mammary glands of mCripto-1 KO mice than the matching control $\mathrm{FVB} / \mathrm{N}$ involuting mammary glands (Figure 5). The increase in cell proliferation in the involuting mammary glands of experimental mCripto-1 KO mice may explain the delayed involution and high epithelial contents in these mammary glands, indicating a role for mCripto-1, in mammary epithelial proliferation and involution.

The comparable mammary epithelial content of the 10week-old nulliparous FVB/N and age-matched experimental mice mammary glands indicates that mCripto- 1 does not have an apparent effect on the proliferation of ductal epithelial cell proliferation in mammary glands of nulliparous females. However, mCripto- 1 expression is essential for the mammary lobulo-alveolar development. Mammary lobules and alveoli start to expand at day 5 of pregnancy ${ }^{24}$ and continue their growth and differentiation during gestation to form functionally active glandular structures that produce and secrete milk proteins during lactation. The defect in lobulo-alveolar development in the mammary glands of mCripto-1-deficient mice results in a failure to produce sufficient amounts of milk. This is reflected by a decrease in the pups' weight (Figure 6A). Even though the starting birth weight was the same in the experimental and control pups, MMTV-CRKO pups showed the least weight gain, followed by the WAP-CRKO compared with FVB/N pups. In addition to a defect in lobulo-alveolar development and a subsequent reduction in milk production, expression levels of mRNA for the major milk proteins, WAP, and $\beta$-casein were significantly reduced in the mammary glands of the conditional mCripto-1 KO mice (Figure 6, B and C), respectively, with the lowest levels in the MMTV-CRKO mice. These data show that mCripto-1 expression is essential for normal mammary lobulo-alveolar development.

Mammary gland involution takes place after lactation. Involution results in the return of the mammary gland to a morphological stage almost comparable to prepregnancy in nulliparous mice. This developmental stage is characterized by a high degree of epithelial cell apoptosis and tissue remodeling. ${ }^{25}$ The delayed involution, high epithelial content, and high epithelial proliferation rate in the 3-day involuting mammary glands of experimental mCripto-1 KO mice led us to investigate the rate of apoptosis in these mammary glands (Figure 7). The percentage of apoptotic cells was lower in the WAPCRKO and MMTV-CRKO mice than in FVB/N mammary glands during early involution ( 3 days involution), with the MMTV-CRKO mammary glands showing the most significant reduction in apoptosis (Figure 7). These results indicate that loss of mCripto-1 expression results in decreased apoptosis of mammary alveolar epithelial cells during involution. Thus, the high proliferation and low apoptosis rates in the involuting mammary glands of the mCripto- $1 \mathrm{KO}$ mice can explain the delayed involution.

We examined mammary gland development from MMTV-CRKO and WAP-CRKO mice in subsequent pregnancies and did not observe a significant developmental impairment as we had detected during the first pregnancy. A common problem with many deleter lines is 

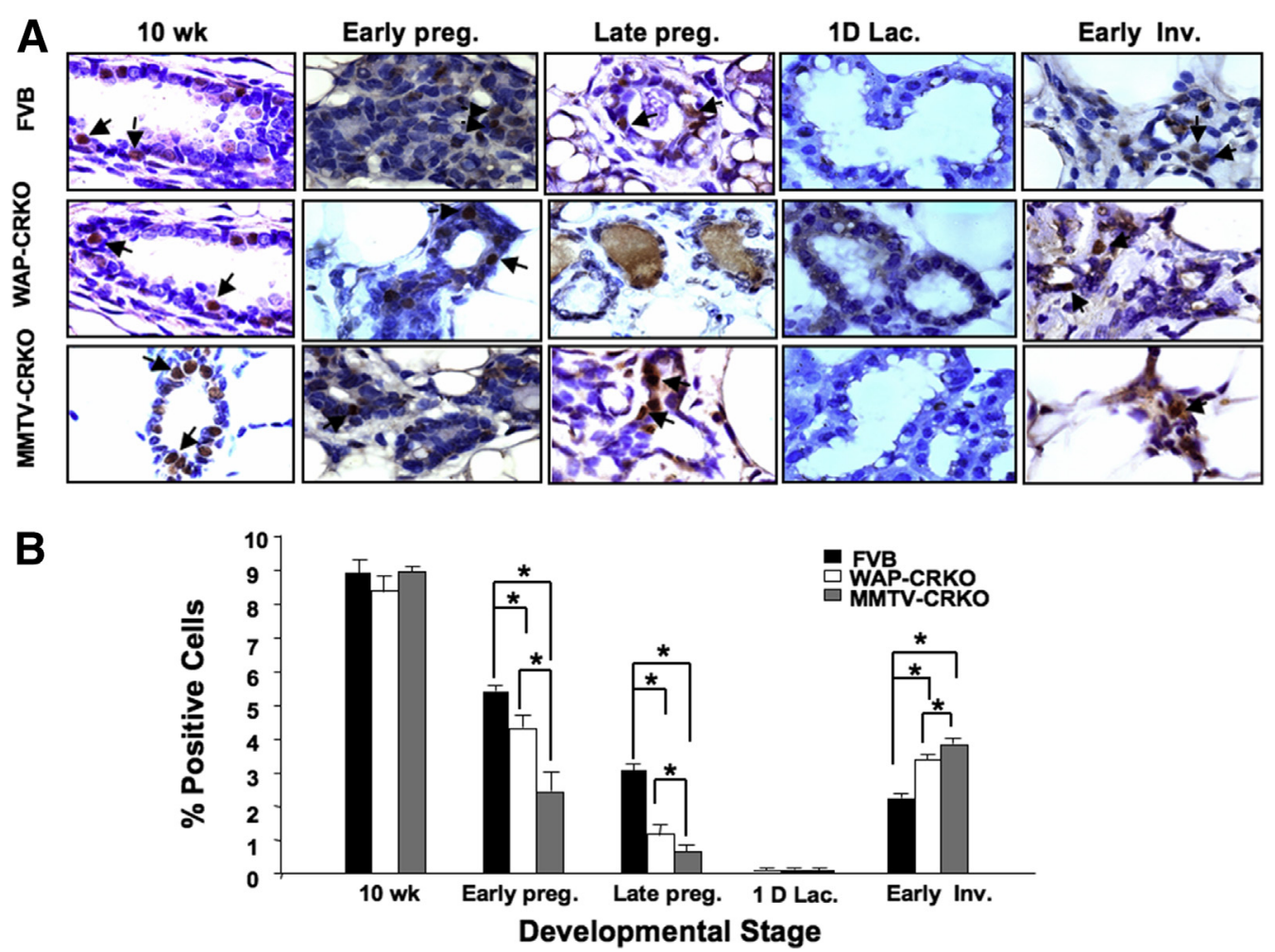

Figure 5 Effects of early and late deletion of mouse Cripto-1 on proliferation. Proliferation-positive cells were scored and labeling index expressed as a percentage of positive nuclei from at least 3000 counted cells in mammary glands. A: Representative immunohistochemical sections of mammary tissue collected from FVB/N, whey acidic protein-Cre ${ }^{+} /$Cripto $^{\text {flox }}$ (WAP-CRKO), and MMTV-Cre ${ }^{+} /$Cripto $^{\text {flox }}$ (MMTV-CRKO) mice at indicated times: 10-week-old nulliparous females (10 wk), 6 days pregnancy (Early preg.), 15 days pregnancy (Late preg.), one day lactation (1D lac.), and 3 days involution (Early Inv.). Mouse tissue was fixed and processed for proliferation marked by proliferating cell nuclear antigen expression, as described in Materials and Methods. Arrows indicate representative positive cells for proliferation. B: Positive cells were scored and labeling index was expressed as a percentage of positive nuclei from 3000 counted cells. Mammary epithelial proliferation is significantly lower in the WAP-CRKO and MMTV-CRKO mice mammary glands than the matching FVB/N mice for early and late pregnancy. Also, mammary epithelial proliferation of MMTV-CRKO is significantly lower than WAP-CRKO for early and late pregnancy. In contrast, cell proliferation is significantly higher in the 3 days involuting mammary glands of mCripto-1 KO mice than the matching control FVB/ $\mathrm{N}$ involuting mammary glands. A total of at least five to six mice were used for each experiment. ${ }^{*} P<0.05$. Original magnification, $\times 100$ (A).

that the conditional deletion induces incomplete excision of the targeted allele, leading to mosaicism of the mouse. ${ }^{26}$ As a result of partial gene inactivation, a population of cells with preserved gene expression can produce normal mammary gland development. In addition, it is known that critical requirements of endogenous Cripto-1 expression are spatially and temporally regulated. Cripto- 1 expression in the adult satellite cell compartment enhances only early regeneration of skeletal muscle in a mouse model of acute injury. ${ }^{27}$ Interestingly, although we did not observe the same phenotype of stunted visible alveolar development during first pregnancy, glands from the second pregnancy were significantly smaller and the epithelial component was condensed (data not shown). This additional phenotype may suggest that the epithelial component was rescued because of mosaicism. Remarkably, in Cripto-1 transgenic mice, Cripto-1 can be detected in the mesenchyme surrounding the mammary placodes but not in the epithelial placodes. ${ }^{11}$ Postnatally, Cripto-1 can also be detected at low levels in myoepithelial cells. ${ }^{12}$ Furthermore, we also found Cripto-1 expression in adipocytes (unpublished data, D.S.S.).

\section{mCripto-1 and PR Interaction}

Ovarian steroid hormones, estrogen and progesterone, play a critical role in regulating mammary gland development and growth. ${ }^{28}$ The expression of the PR in the mammary gland is tightly regulated by estrogen. ${ }^{23}$ Therefore, PR expression serves as a marker for both estrogen and progesterone action during various developmental states in the mammary gland. ${ }^{29} \mathrm{PR}$ is first detected in the mouse mammary gland at 7 weeks of age and is regulated by estrogen. ${ }^{30}$ PRKO mice do not exhibit estrous cycles; therefore, they cannot breed and mammary gland development is arrested at the stage of ductal development. ${ }^{31}$ Transplantation of PRKO mammary tissue fragments ${ }^{32}$ or cells into a WT cleared mammary fat pad does not overcome the lack of side branching and lobulo-alveolar development in pregnant mice, ${ }^{32}$ which supports a role of PR in regulating alveolar development. IHC analysis of the WAP-CRKO and MMTV-CRKO mammary glands showed a significantly lower level of PR expression in the WAP-CRKO and MMTV-CRKO mammary glands than the FVB/N control mice during pregnancy and involution (Figure 8, A and B), 

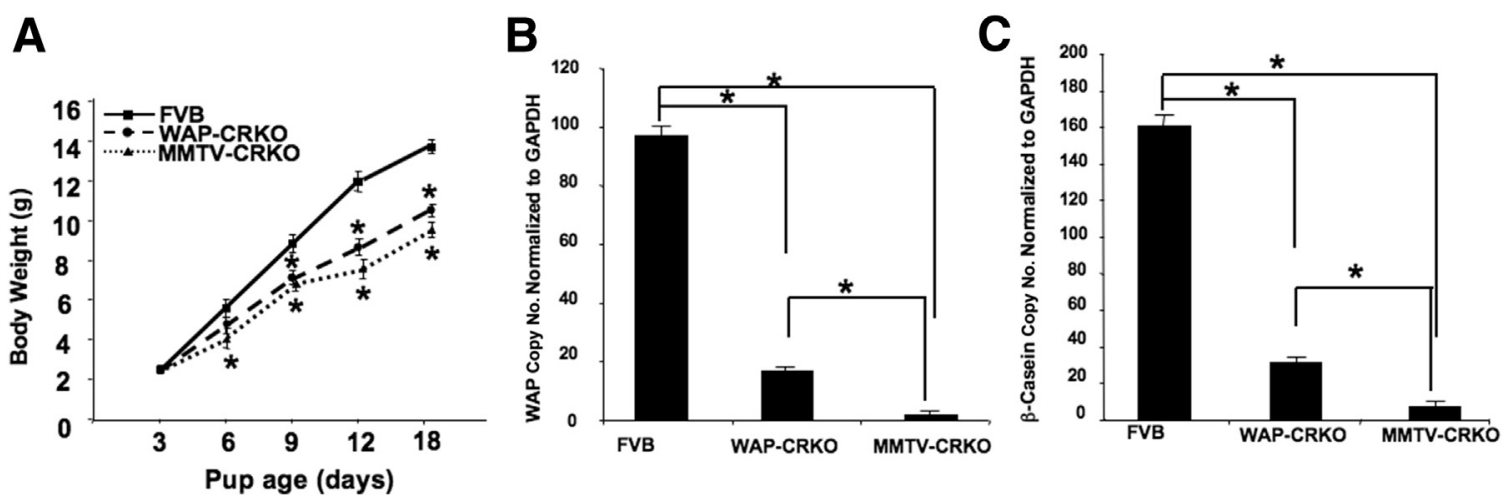

Figure 6 Pup postnatal weight and quantitative RT-PCR (RT-qPCR) analysis of whey acidic protein (WAP) and $\beta$-casein RNA in FVB/N, whey acidic protein$\mathrm{Cre}^{+} /$Cripto $^{\text {flox }}$ (WAP-CRKO), and MMTV-Cre ${ }^{+} /$Cripto $^{\text {flox }}$ (MMTV-CRKO) mice mammary glands. A: Pregnant dams were removed from the breeding cages and placed in separate cages. Litter size was restricted to six pups. Pups' body weights were measured daily at 9 AM and were used to determine the growth rate of the pups. Initially, on day 3 of the study, there are no significant differences in the weights of the pups. However, by day 9 , the mouse Cripto-1 K0 pups weigh less than their FVB/N counterparts; by day 18, the difference is highly significant versus FVB/N. In day 12 and 18 MMTV-CRKO pups, body weight is significantly lower than the matching FVB/N and WAP-CRKO pups. B: RT-qPCR analysis of WAP RNA. C: RT-qPCR analysis of $\beta$-casein RNA. Total mammary gland RNA was used to test for $\beta$-casein and WAP expression, as described in Materials and Methods. Data represent means \pm SEM $(\mathbf{A}-\mathbf{C}) . n=10$ mice per group $(\mathbf{A}-\mathbf{C})$. ${ }^{*} P<0.05$. GAPDH, glyceraldehyde-3-phosphate dehydrogenase.

which indicates that mCripto- 1 can regulate PR expression and/or the levels of PR protein. Also, PR levels were significantly lower in the MMTV-CRKO mammary glands than WAP-CRKO mammary glands of pregnant mice (Figure 8, A and B). We also performed RT-qPCR analysis of PR expression in mammary glands of FVB/N control and MMTV-CRKO mice in early pregnancy, which confirmed our IHC findings (Supplemental Figure S2).

Conditional mCripto- 1 deletion in the mouse mammary gland significantly decreased proliferation, side branching, and lobulo-alveolar structures during early and late pregnancy. To dissect the molecular mechanisms underlying these different physiological effects of mCripto- 1 in the mammary gland, we investigated potential mCripto- 1 and progesterone/PR interactions. To test the effects of Cripto-1 on PR expression (Figure 8C), we constructed a reporter system with a $1.5-\mathrm{kb}$ PR promoter in a gaussian luciferase vector (PR-luc). Then, we transiently transfected the PR-luc promoter plasmid with and without a Cripto-1 expression vector into 293 T cells. Cripto- 1 significantly increased PR expression $(P<0.05)$, indicating regulation of $\mathrm{PR}$ by Cripto-1. PR binds to a specific DNA sequence, the progesterone response element (PRE). ${ }^{33,34}$ Analysis of the 2000-bp upstream region of the mCripto-1 promoter revealed two potential and distinct PREs, with one perfect PRE at -968 to -954 AGCACAGACTGCTCT, and another imperfect PRE at -1172 to -1760 GNACACCTGTTC (Figure 9A), as well as several additional PREs at approximately $3000 \mathrm{bp}$ upstream of the promoter. These data suggest that binding of the progesterone/PR complex to the $m$ Cripto-1 promoter could lead to its activation. To test this hypothesis, PR-positive T47D human breast cancer cells were transfected with a mCripto-1-Luc reporter construct and treated with increasing concentrations of progesterone. Addition of progesterone increased the mCripto-1-driven luciferase activity in a dose-dependent manner, with a onefold increase in the mCripto-1-Luc promoter activity at $50 \mu \mathrm{mol} / \mathrm{L}$ and almost a threefold increase at $100 \mu \mathrm{mol} / \mathrm{L}$ of
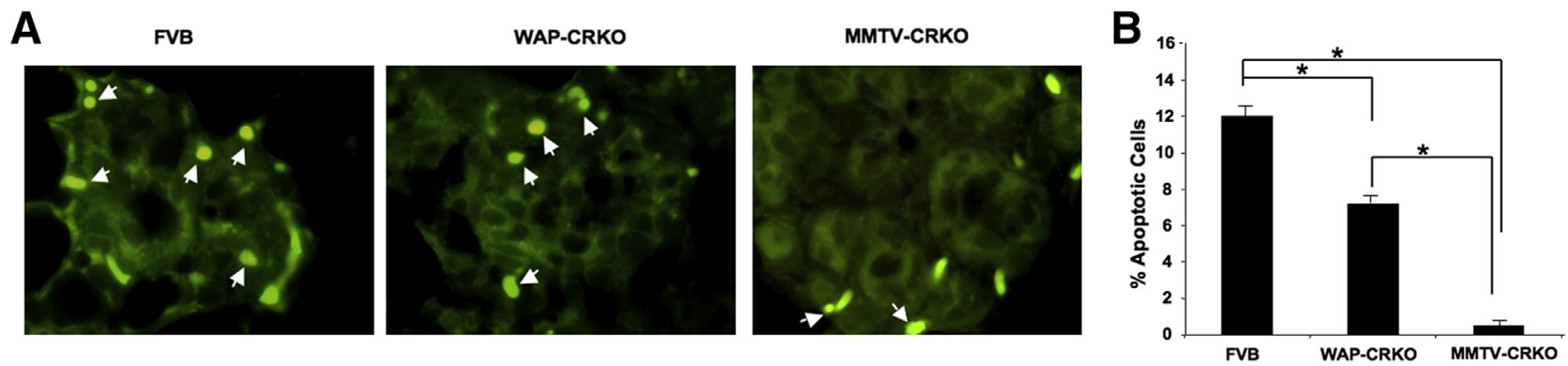

Figure 7 Effects of early and late deletion of mouse Cripto-1 on apoptosis. A: Mammary tissue from early involuting (3 days involution) FVB/N, whey acidic protein-Cre $\mathrm{Cripto}^{\text {flox }}$ (WAP-CRK0), and MMTV-Cre $/$ Cripto flox (MMTV-CRK0) mice was collected and processed for apoptosis by immunohistochemistry, as described in Materials and Methods. Arrows indicate representative apoptotic cells. B: Apoptotic cells were scored, and labeling index was expressed as a percentage of positive nuclei of at least 3000 counted cells. Percentage apoptosis of tunnel-positive cells is significantly lower in the mammary glands of WAP-CRKO and MMTV-CRKO than the FVB/N. Also, apoptosis of MMTV-CRKO is significantly lower than WAP-CRKO. A total of at least five to six mice were used for each experiment. ${ }^{*} P<0.05$. Original magnification, $\times 100(\mathbf{A})$. 

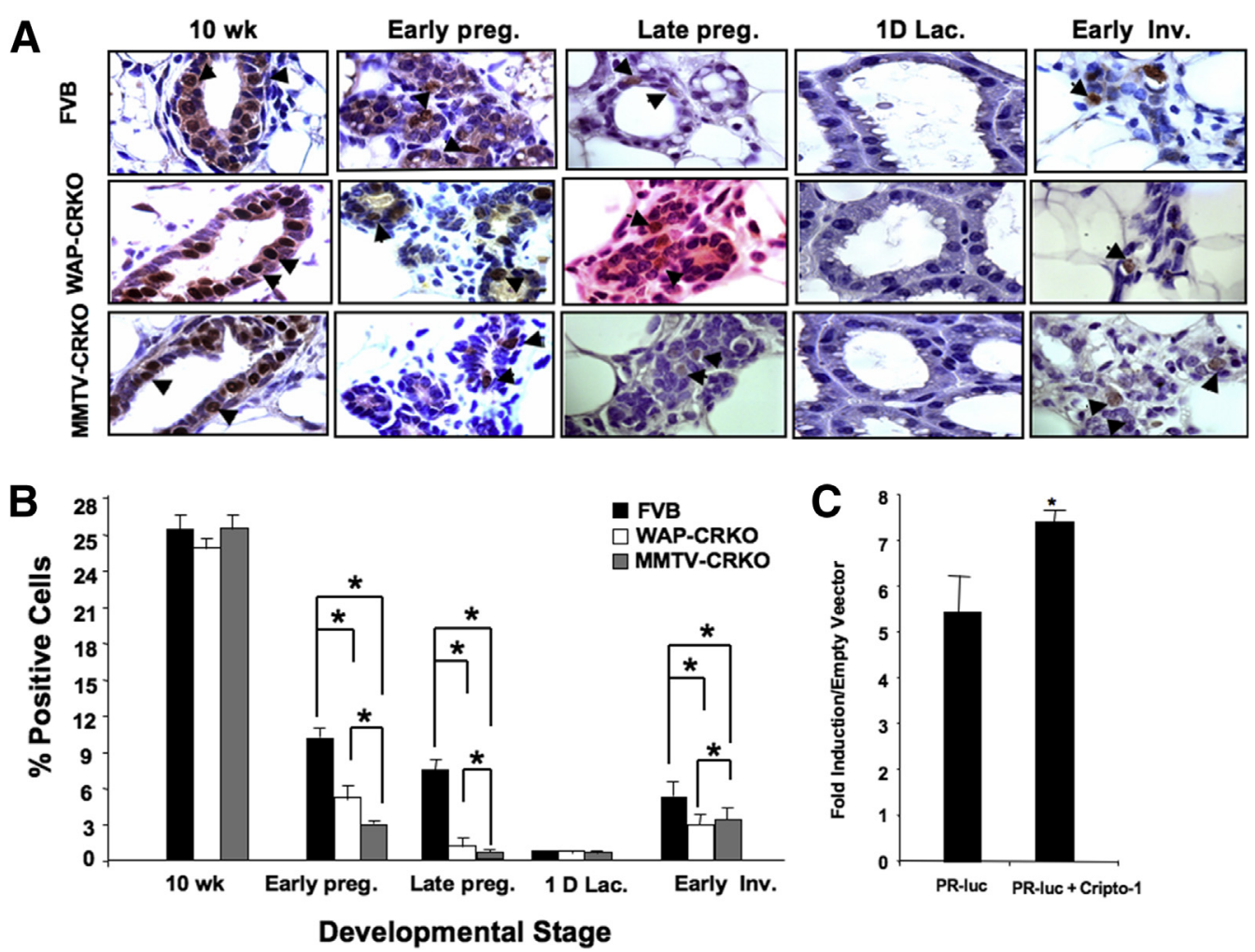

Figure 8 Effects of early and late deletion of mouse Cripto-1 on progesterone receptor (PR) expression. Representative PR-positive cells. A: Immunohistochemical analysis of mammary tissue collected from FVB/N, whey acidic protein-Cre ${ }^{+} /$Cripto $^{\text {flox }}$ (WAP-CRKO), and MMTV-Cre ${ }^{+} /$Cripto $^{\text {flox }}$ (MMTV-CRK0) mice at the indicated times: 10-week-old nulliparous females (10 wk), 6 days pregnancy (Early preg.), 15 days pregnancy (Late preg.), one day lactation (1D lac.), and 3 days involution (Early Inv.). Tissue was fixed and processed for PR expression, as described in Materials and Methods. Arrowheads indicate representative PR-positive cells. B: PR-positive cells were scored, and labeling index was expressed as a percentage of positive nuclei from 3000 counted cells. PR levels were significantly lower in the mouse Cripto-1 K0 mice than FVB/N mice. C: Effect of Cripto-1 on PR expression. 293T cells were transiently transfected with a PR promoter luciferase reporter vector, in the presence or absence of mouse Cripto-1 expression vector. Data show significant increase in PR promoter activity in presence of mouse Cripto-1 expression vector is present. The results are the means \pm SEM from two independent experiments with triplicate samples per experiment $(\mathbf{B}$ and $\mathbf{C}) .{ }^{*} P<0.05$. Original magnification, $\times 100(\mathbf{A})$.

progesterone (Figure 9B). These results indicate the need for high progesterone concentrations for the mCripto-l promoter to reach maximum activity in vitro. Furthermore, we investigated whether progesterone/PR can induce mCripto-1 expression in vivo. We treated 9-week-old intact (WT) female mice with progesterone for 5 days. RT-qPCR analysis showed induction of mCripto-1 expression in mammary glands of the progesterone-treated mice versus control (Figure 9C).

mCripto-1 Role in Mammary Alveolar Development Is Dependent on RANK/RANKL Ratio

RANK and RANKL control bone regeneration and remodeling. ${ }^{35}$ They are also involved in normal mammary gland development and tumorigenesis as a paracrine effector. ${ }^{36,37}$ It has been reported that RANKL is responsible for the major proliferative response of the mouse mammary epithelium to progesterone, ${ }^{37}$ which links the RANK/RANKL axis to progesterone. Progesterone induces RANKL and other target genes in a PR-dependent manner. ${ }^{38}$ IHC analysis of RANKL and RANK in mammary glands of early and late pregnant mice was performed using a fluorescein-conjugated secondary antibody detection system. This allowed the quantitation of fluorescence intensity as a measure of RANKL and RANK concentration per cell. During early pregnancy, RANKL concentration in WAP-CRKO and MMTV-CRKO mammary glands was significantly lower than the concentration in the matching FVB/N control mice (Figure 10A). In contrast, RANK levels in the mammary gland of early pregnant (6 days) mice were higher in the mCripto-1 KO mammary glands than in mammary glands from matched FVB/N mice (Figure 10B). In late pregnancy, RANKL and RANK levels were lower in the mammary glands from Cripto-1 KO mice than in mammary glands from matching FVB/N mice. To validate these data, we performed also RTqPCR analysis of RANKL and RANK expression in mammary glands of FVB/N control and MMTV-CRKO mice in early pregnancy, which confirmed our findings (Supplemental Figure S2). The RANKL/RANK ratio is critical for proper signaling and normal mammary development. ${ }^{37}$ The RANKL/RANK ratio was significantly lower in the mammary glands of early and late pregnant mCripto-1 

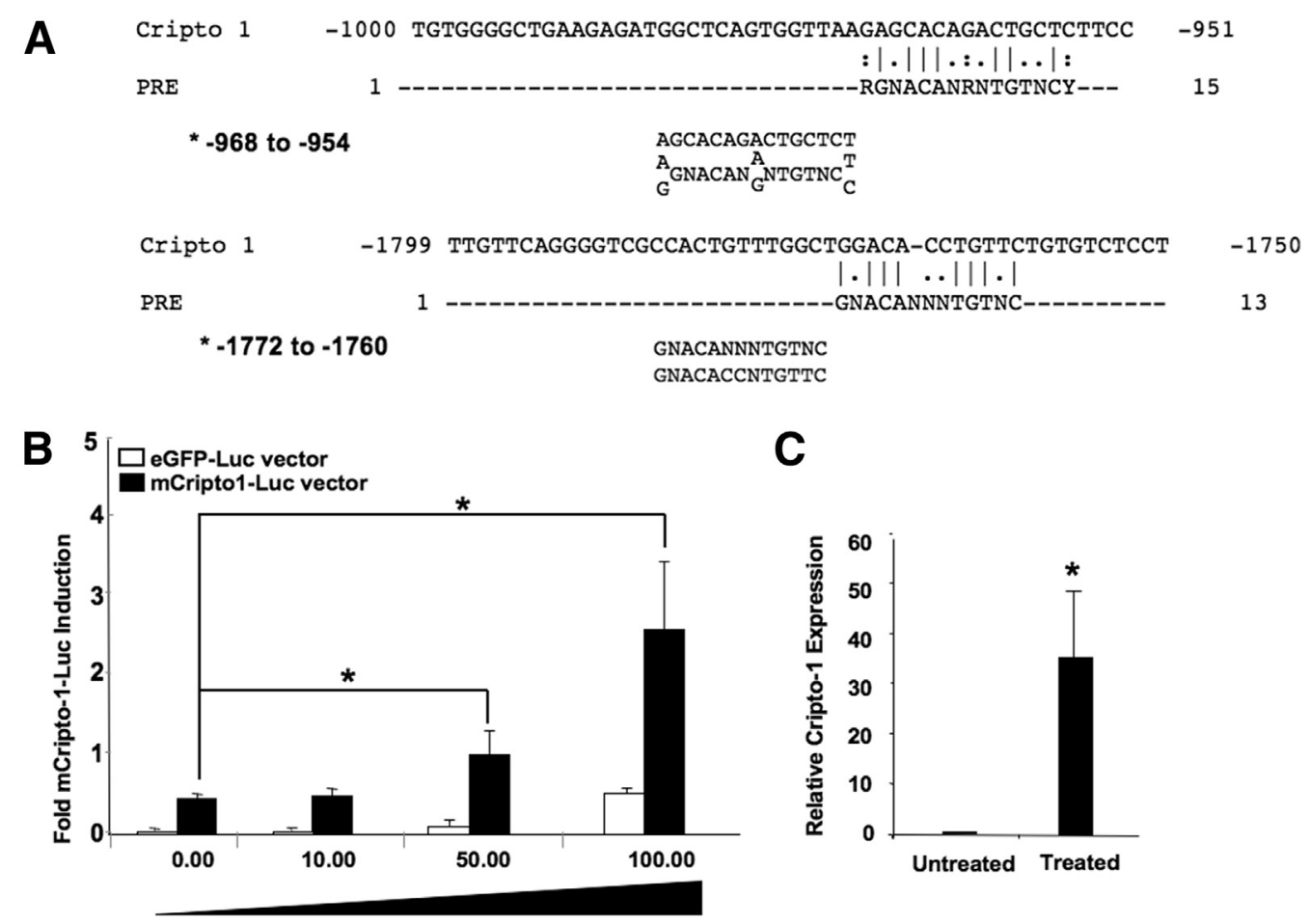

Progesterone Treatment ( $\mu \mathrm{mol} / \mathrm{L})$

Figure 9 Potential progesterone receptor binding sites in the mouse Cripto-1 promoter and activation of Cripto-1 by progesterone. Sequences of two progesterone receptor response elements (PREs) were aligned against 2000 nucleotides up-stream of the $5^{\prime}$ end of the mouse Cripto-1 gene. A: Alignment of the PRE (RGNACANRNTGTNCY) sequences with the mouse Cripto-1 promoter region shows a perfect match at -968 to -954. Alignment of PRE (GNACANNNTGTNC) sequences shows almost a perfect match at nucleotide -1772 to -1760 . B: To demonstrate activation of mouse Cripto-1 promoter by progesterone, T47D cells were transiently transfected with mouse Cripto-1 promoter luciferase reporter vector, in the presence or absence of increasing concentrations of progesterone. Data show a dose-dependent enhancement of mouse Cripto-1 promoter with increasing progesterone concentrations. The results are from two independent experiments with triplicate samples compared with mouse Cripto-1 promoter without progesterone treatment. C: To test the in vivo effects of progesterone on mouse Cripto-1 expression, wild-type intact female mice were injected with progesterone. Total RNA was extracted from mammary tissue and used in quantitative RT-PCR analysis, as described in Materials and Methods. Mammary glands of progesterone-injected females show significantly higher levels of Cripto-1 than control. Data are given as means \pm SEM (B). ${ }^{*} P<0.05$ versus untreated mice. eGFP, enhanced green fluorescent protein.

$\mathrm{KO}$ mice than in $\mathrm{FVB} / \mathrm{N}$ control mammary glands (Figure 10C and Supplemental Figure S2). These data indicate that the mCripto-1 role in alveologenesis is dependent on the ratio of RANKL/RANK.

Binding of RANKL to RANK is an efficient NF- $\kappa \mathrm{B}$ activator. ${ }^{39}$ To characterize the potential role of mCripto- 1 in the activation of NF- $\kappa \mathrm{B}$, we established a dual luciferase/NF- $\kappa \mathrm{B}$ responsive reporter system. Mouse mammary NOG-8 epithelial cells, which are an EGF-responsive, spontaneously immortalized, near diploid, nontransformed mammary epithelial cell that was isolated originally from a mid-pregnant mouse, were transiently cotransfected with a $\mathrm{NF}-\kappa \mathrm{B}$ luciferase responsive plasmid and increasing concentrations of a mCripto-1 expression plasmid. mCripto-1 induced luciferase expression through the NF- $\kappa \mathrm{B}$ promoter (Figure 11A). To validate these data, we characterized the effects of mCripto-1 deletion on NF- $\kappa \mathrm{B}$ targets, cyclin D $1,{ }^{37}$ and $\mathrm{p} 65 .{ }^{40,41} \mathrm{IHC}$ analysis showed a significant reduction in phospho-p65 (Figure 11, B and C) and cyclin D1 (Figure 11, D and E) in the mammary gland of Cripto-1 KO mice compared with control mice. In addition, Western blot and RT-qPCR analyses (Figure 11, F and G) showed a reduction in cyclin D1 protein and expression in the mammary gland of Cripto-1 KO mice compared with FVB/N control mice.

In summary, these results show that mCripto-1 plays a dual role during pregnancy because it is required for proliferation of alveolar epithelial cells and during involution for the remodeling of the mammary gland. These data further suggest that a strict temporal regulation of mCripto-1 expression occurs during mammary gland development and a stage-specific function of mCripto-1 signaling during early pregnancy in mammary gland development. Dissection of the mechanism by which this occurs indicates that mCripto1 can activate RANK/RANKL and NF- $\kappa B$ signaling pathways.

\section{Discussion}

The present study shows a novel mechanism for Cripto-1 regulation of mammary gland development through direct effects on PR expression and pathways regulated by progesterone in the mammary gland. To investigate the 

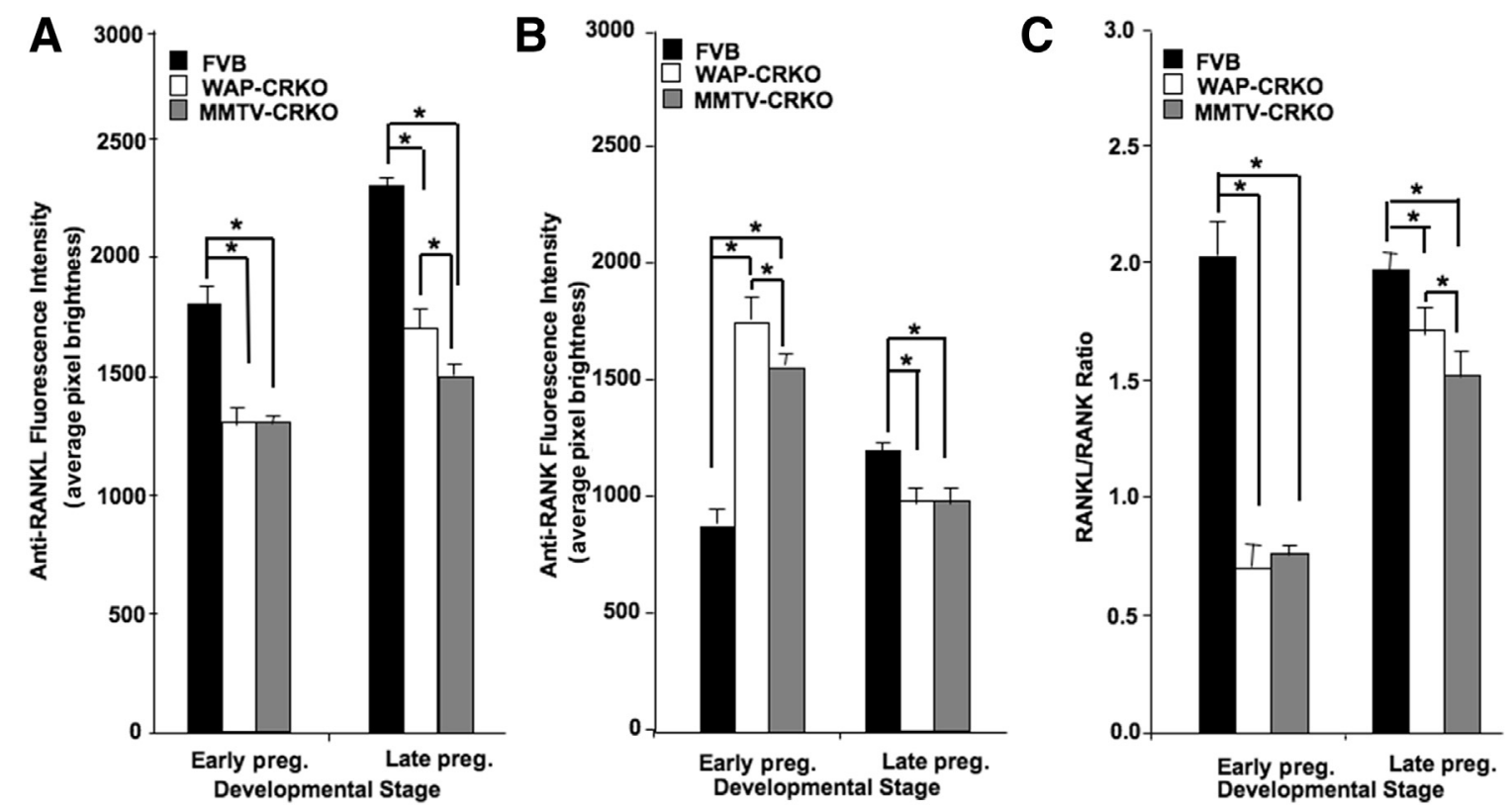

Figure 10 Effects of early and late deletion of mouse Cripto-1 on receptor activator for NF- $K B$ ligand (RANKL) and RANK expression. RANKL (A) and RANK (B) concentrations per cell were quantitated, as described in Materials and Methods. A significant decrease in RANKL is detected in early and late pregnant whey acidic protein-Cre /Cripto $^{\text {flox }}$ (WAP-CRKO), and MMTV-Cre ${ }^{+} /$Cripto $^{\text {flox }}$ (MMTV-CRKO) mice compared with FVB/N mice. B: In contrast, quantitation of RANK shows a significant increase in the expression in the mammary glands of early pregnant mice and a decrease of expression in the late pregnant mammary glands. C: Ratio of RANKL/RANK was significantly lower in the mammary glands of early and late pregnant Cripto-1-knockout mice in comparison to FVB/N mice. Each bar represents the means \pm SEM of a minimum of 3000 cells for each experimental group $(\mathbf{A}-\mathbf{C}) . n=6$ mice for each treatment group $(\mathbf{A}-\mathbf{C})$. ${ }^{*} P<0.05$. Early preg., 6 days pregnancy; Late preg., 15 days pregnancy.

potential role of Cripto-1 in mammary gland development, we generated two different $\mathrm{FVB} / \mathrm{N}$ transgenic mouse lines in which mammary gland expression of Cripto-1 was knocked out in the perinatal mouse mammary gland using the MMTV promoter or during pregnancy using the WAP promoter that is maximally expressed at high levels during late pregnancy and lactation. Our previous transgenic mouse studies have suggested a direct involvement of Cripto-1 in regulating mammary gland branching morphogenesis. ${ }^{10,14,42}$ Mammary glands from Cripto-1 KO nulliparous mice exhibit the same extent of ductal development as is seen in WT FVB/N female mice. However, in mammary glands from early pregnant mice, we observed a significant reduction in side branching and alveolar development in the WAP-CRKO and MMTV-CRKO mice compared with $\mathrm{FVB} / \mathrm{N}$ mice.

Although WAP expression is known to peak in late pregnancy, several reports have shown that the expression of the endogenous WAP promoter is different from WAP promoter-driven transgene expression in mice. For example, Cheng et $\mathrm{al}^{43}$ could detect WAP mRNA and in parallel Cre mRNA in primary mouse mammary epithelial cell preparations at day 7 of the first pregnancy in estrogen receptor knockout mice. In addition, Jhappan et $\mathrm{al}^{44}$ showed that the WAP promoter is minimally active in mammary glands of virgin and 7-day pregnant mice. Moreover, Kordon et $\mathrm{al}^{45}$ showed that the WAP promoter is active in mammary glands of WAP-LACZ mice during estrus. Also, they showed that a few cells in the mammary gland of virgin mice express
WAP protein. These data may explain the phenotype that we observed in the mammary glands of early pregnant mice.

Our data agree with the data of Lydon et al, ${ }^{31}$ where mammary glands of PRKO mice were deficient in alveolar development and did not respond to estrogen and progesterone treatment. Nonetheless, when nulliparous WT females were exposed to estradiol and progesterone, they responded with side branching and lobulo-alveolar development. Our data suggest that Cripto-1, like the PR, is not required for initial ductal growth but is essential for subsequent side branching and alveologenesis during initial stages of pregnancy. Several transgenic models have identified proteins that are essential in maintaining the integrity, function, or development of mammary alveoli, such as erbB4, Stat5a, PR, prolactin receptor, $\beta 1$ integrin, ${ }^{46}$ fibronectin, ${ }^{47}$ and Elf5. ${ }^{48}$ Interestingly, Cripto-1 directly or indirectly regulates the expression of some of them. ${ }^{11}$ Cripto-1 treatment can indirectly induce tyrosine phosphorylation of erbB4. ${ }^{49}$ MMTV-Cripto-1 mammary tumors showed increased expression of several integrins, including integrins $\beta 3, \beta 5, \beta 1$, and $\beta 4$, thereby promoting the activation of focal adhesion kinase, which leads to cell spreading. ${ }^{50}$ Cripto-1 antagonizes Stat5-mediated gene transcription and mammary epithelial cell differentiation and $\beta$-casein production. $5,12,49,51$

Interestingly, CRKO mice exhibited reduced proliferation during pregnancy. In addition, we observed delayed involution likely because of an increase in the proliferation rate and a suppression of apoptosis. Involution of the mouse 


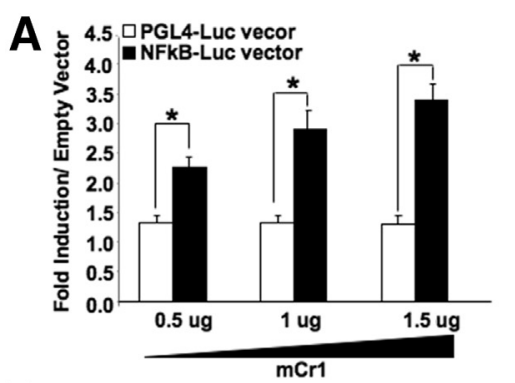

D

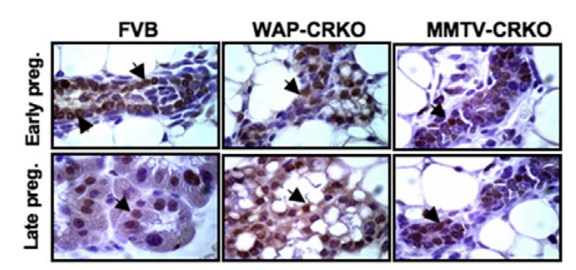

G

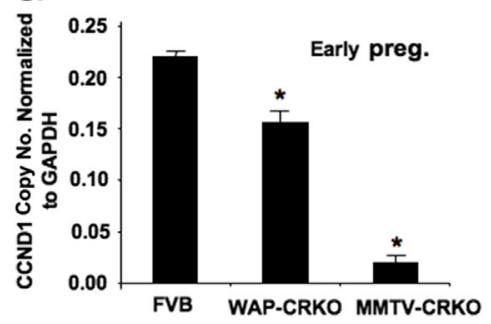

B
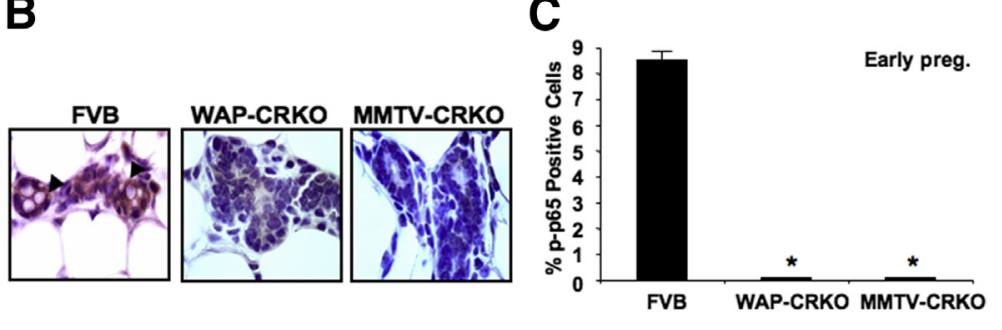

$\mathbf{E}$

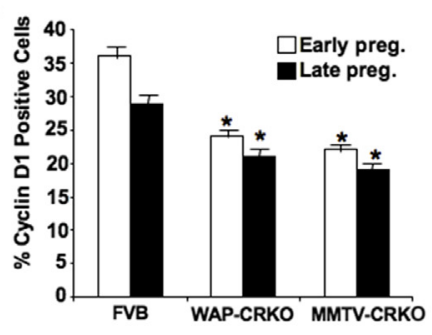

$\mathbf{F}$

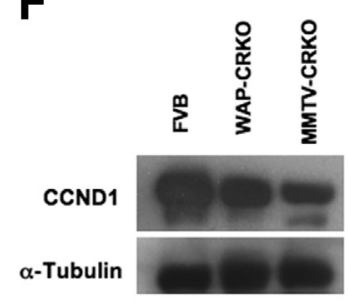

Figure 11 In vivo effect of Cripto-1 deletion on NF- $\mathrm{B}$ activation. A: NOG8 cells were transiently transfected with a NF- $\kappa$ B promoter luciferase reporter vector, in the presence or absence of increasing concentrations of a mouse Cripto-1 expression vector. Data show a dose-dependent increase in NF- $\mathrm{KB}$ promoter activity as the concentration of mouse Cripto-1 expression vector is increased. The results are from two independent experiments with triplicate samples compared with NF-KB promoter transfection of the mouse Cripto-1 expression vector and empty vector PGL4. B: Expression and subcellular localization of phospho-p65 were detected by immunohistochemistry in mammary glands of early pregnant FVB, whey acidic protein-Cre ${ }^{+} / \mathrm{Cripto}^{\text {flox }}$ (WAP-CRK0), and MMTVCRK0 mice. Arrowheads in B indicate representative cells with nuclear translocation of p-p65. C: Quantification of the percentage of phospho-p65-positive cells versus the total number of epithelial cells; percentages of phospho-p65-positive cells are significantly lower in the mammary glands of WAP-CRKO and MMTV-CRKO than the FVB/N mammary gland. D: Representative immunohistochemistry results of cyclin D1 expression in mammary tissue collected from early pregnant and late pregnant FVB/N, whey acidic protein-Cre $e^{+}$Cripto flox (WAP-CRKO), and MMTV-Cre ${ }^{+} /$Cripto $^{\text {flox }}$ (MMTV-CRKO) mice. Arrows in D indicate representative positive cells for cyclin D1. E: Percentages of cyclin D1-positive cells are significantly lower in the mammary glands of early and late pregnant WAP-CRKO and MMTV-CRKO than the FVB/N mice. F: Western blot analysis of cyclin D1 in FVB/N (lane1), WAP-CRKO (lane 2), and MMTV-CRKO (lane 3) mammary protein extracts. G: Quantitative RT-PCR (RT-qPCR) analysis of cyclin D1 in total RNA extracted from WAP-CRK0, MMTV-CRKO, and FVB/N. Each bar represents the ratio of specific mRNA copy number normalized to glyceraldehyde-3-phosphate dehydrogenase (Gapdh) mRNA levels. Cyclin D1 expression is significantly lower in the MMTV-CRKO and WAP-CRKO compared with matching FVB/N. Data are given as means \pm SEM $(\mathbf{A}, \mathbf{C}, \mathbf{E}$, and $\mathbf{G})$. ${ }^{*} P<0.05$. Original magnification, $\times 100$ (B and D). Early preg., 6 days pregnancy; Late preg., 15 days pregnancy; $\mathrm{mCr}$, mouse Cripto; PGL, empty vector.

mammary gland has been extensively characterized morphologically, and several genes are known to be switched on or off during this process. BLG-Stat3 KO mice exhibited a twofold to threefold decrease in the levels of apoptosis and delayed involution compared with WT mice, suggesting that activation of Stat3 at the start of involution acts as an essential death signal for the gland. ${ }^{52}$ Furthermore, expression of singleminded-2s promotes delayed involution of the mouse mammary gland through suppression of Stat 3 and NF- $\kappa B .{ }^{53}$ Cripto-1 can induce activation of the cytoplasmic tyrosine kinase $\mathrm{c}$-src through specifically binding to glypican-1 and GRP78 and also can indirectly interact with the EGF receptor to promote cell survival and proliferation. ${ }^{1}$ Because Stat 3 can be activated by both EGF receptor and c-src, ${ }^{54,55}$ mCripto-1 deletion may reduce Stat3 signaling. Notably, we observed previously increased levels of Stat3 expression in the mammary glands of WAPCripto-1 mice. ${ }^{14}$ Although a potential mechanism of association between Cripto- 1 expression and p-Stat 3 activation is unknown, there are reports that overexpression of Cripto- 1 occurs during the development of gastric cancer by activating a Stat 3 signaling pathway. ${ }^{56}$

The mammary gland is a unique organ because most of its developmental program occurs postnatally. During puberty at the age of 3 to 4 weeks, the mammary gland begins to elongate, with the formation of highly proliferative terminal end buds that invade the mammary fat pad and produce an extensive network of branching ducts that fill the mammary fat pad. ${ }^{57}$ During pregnancy, the mammary gland undergoes alveolar development and side branching in preparation for lactation only to regress to its previous state during involution. This rapid and dynamic process is 


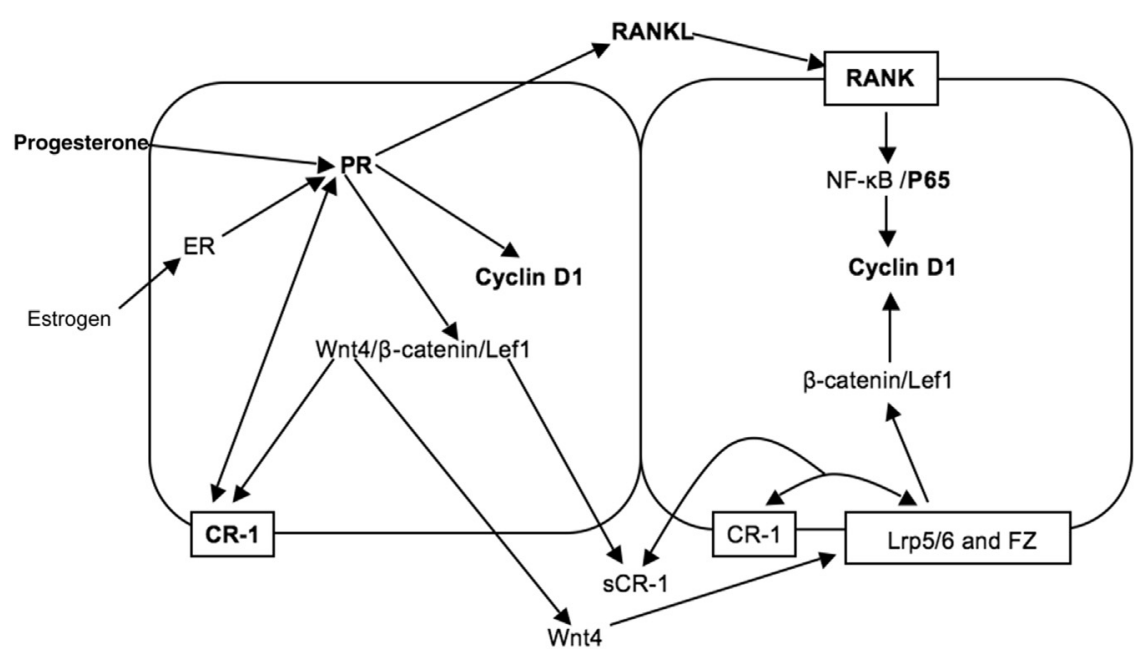

Figure 12 Proposed model. Cripto-1 ablation disrupts alveolar development in the mouse mammary gland through a progesterone receptor (PR)-mediated pathway. Progesterone regulates expression of paracrine effectors, such as receptor activator for NF- $\kappa$ B ligand (RANKL), Wnt4, and Cripto-1. Cripto-1 expression also regulates Wnt/ $\beta$ catenin signaling, which, in turn, can regulate Cripto-1 expression (feed-forward loop). Cripto and $P R$ regulate the expression of each other in a progesterone-dependent manner in a dual feedforward loop. Cripto-1 can affect the ratio of RANK/RANKL, and RANKL through RANK can stimulate NF- $\mathrm{KB}$ activation. Both PR and activated $N F-\kappa B$ can enhance cyclin D1. Boldfaced signaling components represent data from herein. CR, Cripto; ER, estrogen receptor; $F Z$, frizzled; $\mathrm{SCR}$, secreted Cripto.

possible because of the plasticity of the mammary epithelial cells. Activation of Cripto- 1 in the luminal cells most likely contributes to the induction of epithelial plasticity and epithelial-mesenchymal transition. ${ }^{42}$ Pituitary and ovarian hormones tightly control epithelial cell plasticity in the developing mammary gland. Multiple studies have demonstrated that epithelial intrinsic estrogen receptor (ER) $\alpha$ expression is required for ductal elongation, whereas PR expression drives ductal side branching and prolactin receptor expression is necessary for alveologenesis and differentiation into milk-producing cells. ${ }^{58}$ We hypothesize that Cripto-1 directly up-regulates PR expression during early pregnancy; thus, Cripto-1 deletion results in impaired alveolar development and milk protein expression. This later effect would account for the reduced body weight of CRKO pups.

The ovarian hormones estrogen and progesterone control proliferation in the mammary gland. ER-deficient mammary gland development is arrested at the epithelium rudiment stage. ${ }^{59,60} \mathrm{ER} \alpha$ is also critical for the two major phases of mammary development, ductal elongation during puberty and lobulo-alveolar development during early pregnancy. ${ }^{23,29,61,62}$ In the mammary gland, the expression of the PR is tightly regulated by estrogen. ${ }^{23} \mathrm{We}$ investigated whether epithelial cell proliferation was directly affected by loss of mCripto-1. Proliferating cell nuclear antigen staining and epithelial content measurement showed that cell proliferation was comparable in the mammary glands of $\mathrm{FVB} / \mathrm{N}$ and experimental Cripto-1 KO nulliparous mice. However, it was significantly lower in the Cripto-1-deficient mice than in the FVB/N control mice during early pregnancy and late pregnancy mice. Moreover, we analyzed protein levels of the PR at different stages of mammary gland development and showed a significant reduction of the PR receptor during early and late pregnancy. Interestingly, treatment of breast cancer cells with Cripto-1 inhibitors, such as retinoic acid, ${ }^{63,64}$ results in a marked decrease in the levels of PR. ${ }^{65-67}$
To dissect the molecular mechanisms underlying the physiological effects of mCripto-1 in the mammary gland, we investigated the potential interaction between mCripto-1 and progesterone/PR. Analysis of the 2000-bp upstream region in the mCripto- 1 promoter region revealed two potential and distinct PREs. These data suggest that binding of the progesterone/PR complex to the mCripto-1 promoter could lead to its activation. To test this hypothesis, we examined whether the progesterone/PR receptor complex could induce mCripto- 1 expression. We, therefore, inserted $2 \mathrm{~kb}$ of the $5^{\prime}$ flanking region of mCripto- 1 into a luciferase reporter system. We transfected the construct into PRpositive T47D human breast cancer cells and observed a significant increase in the mCripto-1-Luc promoter activity. To detect the Cripto-1 promoter activity, we had to use what seem to be non-physiological (50 to $100 \mu \mathrm{mol} / \mathrm{L}$ ) concentrations of progesterone. It is clear that the $2-\mathrm{kb}$ fragment of the Cripto-1 $5^{\prime}$ flanking region, which we used in the reporter system, is not sufficient to confer responsiveness to physiological ( 5 to $50 \mathrm{nmol} / \mathrm{L}$ ) concentrations of progesterone through the endogenous PR in the T47D breast cancer cells. We performed additional in silico analysis on a longer (3000-bp) fragment of the human and mCripto-1 promoters and confirmed the presence of several additional PRE sequences (data not shown). It is highly possible that these more distal PREs may exhibit a collaborative effect, and the lack of one or more of those additional PRE sequences could significantly reduce the sensitivity of our assay. In this respect, in vivo treatment of nulliparous mice with progesterone significantly increased mCripto-1 expression in the mammary gland. Alveolar formation during pregnancy is dependent on progesterone signaling, through an initial cell proliferation wave during day 2 to day 6 of pregnancy. ${ }^{24}$ Two surges of progesterone levels take place during pregnancy. The first surge takes place on day 3 , and the second surge takes place on day 16 . Progesterone levels peak to $45.5 \mathrm{ng} / \mathrm{mL}$ at day 3 of 
pregnancy and reach $81.9 \mathrm{ng} / \mathrm{mL}$ in late pregnancy (day 16). ${ }^{68}$ Activation of the Cripto-1-Luc reporter by high doses of progesterone (50 to $100 \mu \mathrm{mol} / \mathrm{L}=16$ to $32 \mathrm{ng} / \mathrm{mL}$ ) points to temporal activation of Cripto-1 during mammary development. Reciprocally, Cripto-1 could induce expression of PR through a PR-luc promoter construct, thereby confirming the potential of Cripto-1 in regulating PR expression.

Activation of the PR that is present in a subset of epithelial cells within the mammary gland of mice ${ }^{69}$ stimulates these same cells to produce and secrete RANKL. ${ }^{70}$ Mammary glands of RANK- and RANKL-deficient mice develop normally during sexual maturation, but similar to PRKO and Cripto-1, KO mice fail to form lobulo-alveolar structures during pregnancy because of defective proliferation and increased apoptosis of the mammary epithelium. ${ }^{37}$ The RANKL/RANK axis is also involved in progesteroneinduced activation of cyclin D1. ${ }^{71}$ In this regard, Beleut et $\mathrm{al}^{58}$ showed that progesterone elicits proliferation in the mammary epithelium by two distinct mechanisms; one occurs in PR-positive cells and is cyclin D1 dependent and RANKL independent. Interestingly, we found that in early pregnancy, levels of cyclin D1 and the RANKL/RANK ratio were affected by loss of Cripto-1 in a manner similar to the reduction in PR levels. Cyclin D1 is a downstream target for NF- $\mathrm{BB}$ that is activated by the RANKL/RANK signaling pathway and is reduced in Cripto-1 KO mice. Binding of RANKL to RANK is an efficient NF- $\kappa \mathrm{B}$ activator. ${ }^{39}$ The significant effect of Cripto-1 KO on RANKL and RANK levels and ratio led us to characterize the role of mCripto-1 in the activation of the NF- $\kappa \mathrm{B}$ signaling pathway. We demonstrated that Cripto-1 significantly and in a dosedependent manner activated a luciferase/NF- $\kappa \mathrm{B}$ responsive reporter system in NOG-8 mouse mammary epithelial cells. In addition, our findings in vitro were supported in the Cripto-1 KO animal model, where we showed that the NF$\kappa \mathrm{B}$ targets, cyclin D1 and p-p65, were significantly reduced during pregnancy. Moreover, PR/RANKL pathways are conserved between mouse and human and are believed to be a major regulatory axis in human breast cancer. ${ }^{72}$ Ablation of the nuclear PR in rodents dramatically reduces susceptibility to carcinogenesis. ${ }^{73}$ In addition, like Cripto-1, progesterone can increase cell proliferation and the proportion of normal mammary cells that formed mammospheres in suspensions. ${ }^{74}$ In this regard, progesterone functions in a luminal progenitor population that is PR and ER positive to maintain both ER- and PR-negative luminal progenitors and basal/mammary stem cells through paracrine effectors, such as Wnt4 and RANKL (NF- $\kappa B)^{38,69,75}$ (Figure 12). Interestingly, secreted Cripto-1 has also been demonstrated to be essential through GRP78 in maintaining and regulating a population of fetal and adult mouse mammary stem cells through a phosphatidylinositol 3-kinase/Akt pathway. Because the canonical $\mathrm{Wnt} / \beta$-catenin signaling pathway can enhance Cripto-1 expression ${ }^{76,77}$ and because Cripto-1 can, in turn, amplify Wnt signaling through Lrp5/6 to facilitate binding to $\mathrm{Fzd}^{78}$ this could suggest a positive feedback regulatory loop is possible in both subpopulations of luminal progenitor cells (ie, $\mathrm{ER}^{+/-}$and $\mathrm{PR}^{+/-}$). The ability of $\mathrm{Wnt} / \beta$-catenin, PR, and RANKL/NF- $\kappa \mathrm{B}$ to regulate a common effector, such as cyclin D1, and the ability of progesterone through the PR to regulate Cripto-1 expression as well as Cripto-1 being able to enhance PR expression suggests that Cripto-1 and PR/RANKL might collectively regulate early alveolar development in the mammary gland.

In summary, our present data demonstrate that mCripto-1 plays a dual role during pregnancy because it is required for proliferation of developing alveolar epithelial cells and during involution for the remodeling of the mammary gland. Cripto-1 not only can regulate PR expression but also downstream PR targets, such as RANKL, RANK, and cyclin D1, through a NF- $\kappa \mathrm{B}$ system.

\section{Supplemental Data}

Supplemental material for this article can be found at http://dx.doi.org/10.1016/j.ajpath.2015.07.023.

\section{References}

1. Klauzinska M, Castro NP, Rangel MC, Spike BT, Gray PC, Bertolette D, Cuttitta F, Salomon D: The multifaceted role of the embryonic gene Cripto-1 in cancer, stem cells and epithelialmesenchymal transition. Semin Cancer Biol 2014, 29:51-58

2. Bianco C, Strizzi L, Normanno N, Khan N, Salomon DS: Cripto-1: an oncofetal gene with many faces. Curr Top Dev Biol 2005, 67:85-133

3. Ding J, Yang L, Yan YT, Chen A, Desai N, Wynshaw-Boris A, Shen MM: Cripto is required for correct orientation of the anteriorposterior axis in the mouse embryo. Nature 1998, 395:702-707

4. Chu J, Ding J, Jeays-Ward K, Price SM, Placzek M, Shen MM: Noncell-autonomous role for Cripto in axial midline formation during vertebrate embryogenesis. Development 2005, 132:5539-5551

5. Bianco C, Rangel MC, Castro NP, Nagaoka T, Rollman $\mathrm{K}$, Gonzales M, Salomon DS: Role of Cripto-1 in stem cell maintenance and malignant progression. Am J Pathol 2010, 177:532-540

6. Aasen T, Raya A, Barrero MJ, Garreta E, Consiglio A, Gonzalez F, Vassena R, Bilic J, Pekarik V, Tiscornia G, Edel M, Boue S, Izpisua Belmonte JC: Efficient and rapid generation of induced pluripotent stem cells from human keratinocytes. Nat Biotechnol 2008, 26: $1276-1284$

7. Aoi T, Yae K, Nakagawa M, Ichisaka T, Okita K, Takahashi K, Chiba T, Yamanaka S: Generation of pluripotent stem cells from adult mouse liver and stomach cells. Science 2008, 321:699-702

8. Miharada K, Karlsson G, Rehn M, Rorby E, Siva K, Cammenga J, Karlsson S: Cripto regulates hematopoietic stem cells as a hypoxicniche-related factor through cell surface receptor GRP78. Cell Stem Cell 2011, 9:330-344

9. Spike BT, Kelber JA, Booker E, Kalathur M, Rodewald R, Lipianskaya J, La J, He M, Wright T, Klemke R, Wahl GM, Gray PC: CRIPTO/GRP78 signaling maintains fetal and adult mammary stem cells ex vivo. Stem Cell Reports 2014, 2:427-439

10. Wechselberger C, Strizzi L, Kenney N, Hirota M, Sun Y, Ebert A, Orozco O, Bianco C, Khan NI, Wallace-Jones B, Normanno N, Adkins H, Sanicola M, Salomon DS: Human Cripto-1 overexpression in the mouse mammary gland results in the development of hyperplasia and adenocarcinoma. Oncogene 2005, 24:4094-4105

11. Strizzi L, Mancino M, Bianco C, Raafat A, Gonzales M, Booth BW, Watanabe K, Nagaoka T, Mack DL, Howard B, Callahan R, Smith GH, Salomon DS: Netrin-1 can affect morphogenesis and 
differentiation of the mouse mammary gland. J Cell Physiol 2008, 216:824-834

12. Kenney NJ, Smith GH, Maroulakou IG, Green JH, Muller WJ, Callahan R, Salomon DS, Dickson RB: Detection of amphiregulin and Cripto-1 in mammary tumors from transgenic mice. Mol Carcinog 1996, 15:44-56

13. Wechselberger C, Ebert AD, Bianco C, Khan NI, Sun Y, WallaceJones B, Montesano R, Salomon DS: Cripto-1 enhances migration and branching morphogenesis of mouse mammary epithelial cells. Exp Cell Res 2001, 266:95-105

14. Sun Y, Strizzi L, Raafat A, Hirota M, Bianco C, Feigenbaum L, Kenney N, Wechselberger C, Callahan R, Salomon DS: Overexpression of human Cripto-1 in transgenic mice delays mammary gland development and differentiation and induces mammary tumorigenesis. Am J Pathol 2005, 167:585-597

15. Wagner KU, Wall RJ, St-Onge L, Gruss P, Wynshaw-Boris A, Garrett L, Li M, Furth PA, Hennighausen L: Cre-mediated gene deletion in the mammary gland. Nucleic Acids Res 1997, 25:4323-4330

16. Wagner KU, Krempler A, Qi Y, Park K, Henry MD, Triplett AA, Riedlinger G, Rucker IE, Hennighausen L: Tsg101 is essential for cell growth, proliferation, and cell survival of embryonic and adult tissues. Mol Cell Biol 2003, 23:150-162

17. Wagner KU, McAllister $\mathrm{K}$, Ward $\mathrm{T}$, Davis $\mathrm{B}$, Wiseman $\mathrm{R}$, Hennighausen L: Spatial and temporal expression of the Cre gene under the control of the MMTV-LTR in different lines of transgenic mice. Transgenic Res 2001, 10:545-553

18. Raafat A, Goldhar AS, Klauzinska M, Xu K, Amirjazil I, McCurdy D, Lashin K, Salomon D, Vonderhaar BK, Egan S, Callahan R: Expression of Notch receptors, ligands, and target genes during development of the mouse mammary gland. J Cell Physiol 2011, 226:1940-1952

19. Raafat A, Strizzi L, Lashin K, Ginsburg E, McCurdy D, Salomon D, Smith GH, Medina D, Callahan R: Effects of age and parity on mammary gland lesions and progenitor cells in the FVB/N-RC mice. PLoS One 2012, 7:e43624

20. Raafat A, Lawson S, Bargo S, Klauzinska M, Strizzi L, Goldhar AS, Buono K, Salomon D, Vonderhaar BK, Callahan R: Rbpj conditional knockout reveals distinct functions of Notch4/Int3 in mammary gland development and tumorigenesis. Oncogene 2009, 28:219-230

21. Raafat A, Zoltan-Jones A, Strizzi L, Bargo S, Kimura K, Salomon D, Callahan R: Kit and PDGFR-alpha activities are necessary for Notch4/Int3-induced tumorigenesis. Oncogene 2007, 26:662-672

22. Wagner KU, Boulanger CA, Henry MD, Sgagias M, Hennighausen L, Smith GH: An adjunct mammary epithelial cell population in parous females: its role in functional adaptation and tissue renewal. Development 2002, 129:1377-1386

23. Feng Y, Manka D, Wagner KU, Khan SA: Estrogen receptor-alpha expression in the mammary epithelium is required for ductal and alveolar morphogenesis in mice. Proc Natl Acad Sci U S A 2007, 104:14718-14723

24. Oakes SR, Hilton HN, Ormandy CJ: The alveolar switch: coordinating the proliferative cues and cell fate decisions that drive the formation of lobuloalveoli from ductal epithelium. Breast Cancer Res 2006, 8:207

25. Stein T, Salomonis N, Gusterson BA: Mammary gland involution as a multi-step process. J Mammary Gland Biol Neoplasia 2007, 12: $25-35$

26. Bockamp E, Maringer M, Spangenberg C, Fees S, Fraser S, Eshkind L, Oesch F, Zabel B: Of mice and models: improved animal models for biomedical research. Physiol Genomics 2002, 11: $115-132$

27. Prezioso C, Iaconis S, Andolfi G, Zentilin L, Iavarone F, Guardiola O, Minchiotti G: Conditional Cripto overexpression in satellite cells promotes myogenic commitment and enhances early regeneration. Front Cell Dev Biol 2015, 3:31

28. Raafat AM, Li S, Bennett JM, Hofseth LJ, Haslam SZ: Estrogen and estrogen plus progestin act directly on the mammary gland to increase proliferation in a postmenopausal mouse model. J Cell Physiol 2001, 187:81-89

29. Shyamala G, Chou YC, Louie SG, Guzman RC, Smith GH, Nandi S: Cellular expression of estrogen and progesterone receptors in mammary glands: regulation by hormones, development and aging. J Steroid Biochem Mol Biol 2002, 80:137-148

30. Fendrick JL, Raafat AM, Haslam SZ: Mammary gland growth and development from the postnatal period to postmenopause: ovarian steroid receptor ontogeny and regulation in the mouse. J Mammary Gland Biol Neoplasia 1998, 3:7-22

31. Lydon JP, DeMayo FJ, Funk CR, Mani SK, Hughes AR, Montgomery CA Jr, Shyamala G, Conneely OM, O’Malley BW: Mice lacking progesterone receptor exhibit pleiotropic reproductive abnormalities. Genes Dev 1995, 9:2266-2278

32. Brisken C, Park S, Vass T, Lydon JP, O’Malley BW, Weinberg RA: A paracrine role for the epithelial progesterone receptor in mammary gland development. Proc Natl Acad Sci U S A 1998, 95:5076-5081

33. Lieberman BA, Bona BJ, Edwards DP, Nordeen SK: The constitution of a progesterone response element. Mol Endocrinol 1993, 7: $515-527$

34. Yin $\mathrm{P}$, Roqueiro D, Huang L, Owen JK, Xie A, Navarro A, Monsivais D, Coon JS 5th, Kim JJ, Dai Y, Bulun SE: Genome-wide progesterone receptor binding: cell type- specific and shared mechanisms in T47D breast cancer cells and primary leiomyoma cells. PLoS One 2012, 7:e29021

35. Hofbauer LC, Rachner T, Singh SK: Fatal attraction: why breast cancer cells home to bone. Breast Cancer Res 2008, 10:101

36. Jones DH, Nakashima T, Sanchez OH, Kozieradzki I, Komarova SV, Sarosi I, Morony S, Rubin E, Sarao R, Hojilla CV, Komnenovic V, Kong YY, Schreiber M, Dixon SJ, Sims SM, Khokha R, Wada T, Penninger JM: Regulation of cancer cell migration and bone metastasis by RANKL. Nature 2006, 440:692-696

37. Fata JE, Kong YY, Li J, Sasaki T, Irie-Sasaki J, Moorehead RA, Elliott R, Scully S, Voura EB, Lacey DL, Boyle WJ, Khokha R, Penninger JM: The osteoclast differentiation factor osteoprotegerinligand is essential for mammary gland development. Cell 2000, $103: 41-50$

38. Obr AE, Grimm SL, Bishop KA, Pike JW, Lydon JP, Edwards DP: Progesterone receptor and Stat5 signaling cross talk through RANKL in mammary epithelial cells. Mol Endocrinol 2013, 27:1808-1824

39. Anderson DM, Maraskovsky E, Billingsley WL, Dougall WC, Tometsko ME, Roux ER, Teepe MC, DuBose RF, Cosman D, Galibert L: A homologue of the TNF receptor and its ligand enhance T-cell growth and dendritic-cell function. Nature 1997, 390:175-179

40. Toualbi-Abed K, Daniel F, Guller MC, Legrand A, Mauriz JL, Mauviel A, Bernuau D: Jun D cooperates with p65 to activate the proximal kappaB site of the cyclin D1 promoter: role of PI3K/PDK-1. Carcinogenesis 2008, 29:536-543

41. Gilmore TD: Introduction to NF-kappaB: players, pathways, perspectives. Oncogene 2006, 25:6680-6684

42. Rangel MC, Karasawa H, Castro NP, Nagaoka T, Salomon DS, Bianco C: Role of Cripto-1 during epithelial-to-mesenchymal transition in development and cancer. Am J Pathol 2012, 180:2188-2200

43. Cheng G, Weihua Z, Warner M, Gustafsson JA: Estrogen receptors ER alpha and ER beta in proliferation in the rodent mammary gland. Proc Natl Acad Sci U S A 2004, 101:3739-3746

44. Jhappan C, Geiser AG, Kordon EC, Bagheri D, Hennighausen L, Roberts AB, Smith GH, Merlino G: Targeting expression of a transforming growth factor beta 1 transgene to the pregnant mammary gland inhibits alveolar development and lactation. EMBO J 1993, 12: $1835-1845$

45. Kordon EC, McKnight RA, Jhappan C, Hennighausen L, Merlino G, Smith GH: Ectopic TGF beta 1 expression in the secretory mammary epithelium induces early senescence of the epithelial stem cell population. Dev Biol 1995, 168:47-61

46. Brisken C, Rajaram RD: Alveolar and lactogenic differentiation. J Mammary Gland Biol Neoplasia 2006, 11:239-248 
47. Liu K, Cheng L, Flesken-Nikitin A, Huang L, Nikitin AY, Pauli BU: Conditional knockout of fibronectin abrogates mouse mammary gland lobuloalveolar differentiation. Dev Biol 2010, 346:11-24

48. Chakrabarti R, Wei Y, Romano RA, DeCoste C, Kang Y, Sinha S: Elf5 regulates mammary gland stem/progenitor cell fate by influencing notch signaling. Stem Cells 2012, 30:1496-1508

49. Kannan S, De Santis M, Lohmeyer M, Riese DJ 2nd, Smith GH, Hynes N, Seno M, Brandt R, Bianco C, Persico G, Kenney N, Normanno N, Martinez-Lacaci I, Ciardiello F, Stern DF, Gullick WJ, Salomon DS: Cripto enhances the tyrosine phosphorylation of Shc and activates mitogen-activated protein kinase (MAPK) in mammary epithelial cells. J Biol Chem 1997, 272:3330-3335

50. Strizzi L, Bianco C, Normanno N, Seno M, Wechselberger C, Wallace-Jones B, Khan NI, Hirota M, Sun Y, Sanicola M, Salomon DS: Epithelial mesenchymal transition is a characteristic of hyperplasias and tumors in mammary gland from MMTV-Cripto-1 transgenic mice. J Cell Physiol 2004, 201:266-276

51. Cocolakis E, Dai M, Drevet L, Ho J, Haines E, Ali S, Lebrun JJ: Smad signaling antagonizes STAT5-mediated gene transcription and mammary epithelial cell differentiation. J Biol Chem 2008, 283: $1293-1307$

52. Chapman RS, Lourenco P, Tonner E, Flint D, Selbert S, Takeda K, Akira S, Clarke AR, Watson CJ: The role of Stat3 in apoptosis and mammary gland involution: conditional deletion of Stat3. Adv Exp Med Biol 2000, 480:129-138

53. Scribner KC, Wellberg EA, Metz RP, Porter WW: Singleminded-2s (Sim2s) promotes delayed involution of the mouse mammary gland through suppression of Stat3 and NFkappaB. Mol Endocrinol 2011, 25:635-644

54. Silva CM: Role of STATs as downstream signal transducers in Src family kinase- mediated tumorigenesis. Oncogene 2004, 23:8017-8023

55. Quesnelle KM, Boehm AL, Grandis JR: STAT-mediated EGFR signaling in cancer. J Cell Biochem 2007, 102:311-319

56. Zhang JG, Zhao J, Xin Y: Significance and relationship between Cripto-1 and p- STAT3 expression in gastric cancer and precancerous lesions. World J Gastroenterol 2010, 16:571-577

57. Sternlicht MD: Key stages in mammary gland development: the cues that regulate ductal branching morphogenesis. Breast Cancer Res 2006, 8:201

58. Beleut M, Rajaram RD, Caikovski M, Ayyanan A, Germano D, Choi Y, Schneider P, Brisken C: Two distinct mechanisms underlie progesterone-induced proliferation in the mammary gland. Proc Natl Acad Sci U S A 2010, 107:2989-2994

59. Emmen JM, Korach KS: Estrogen receptor knockout mice: phenotypes in the female reproductive tract. Gynecol Endocrinol 2003, 17: 169-176

60. Hewitt SC, Korach KS: Oestrogen receptor knockout mice: roles for oestrogen receptors alpha and beta in reproductive tissues. Reproduction 2003, 125:143-149

61. Bocchinfuso WP, Lindzey JK, Hewitt SC, Clark JA, Myers PH, Cooper R, Korach KS: Induction of mammary gland development in estrogen receptor-alpha knockout mice. Endocrinology 2000, 141: 2982-2994

62. Olsson H, Jernstrom H, Alm P, Kreipe H, Ingvar C, Jonsson PE, Ryden S: Proliferation of the breast epithelium in relation to menstrual cycle phase, hormonal use, and reproductive factors. Breast Cancer Res Treat 1996, 40:187-196

63. Hentschke M, Kurth I, Borgmeyer U, Hubner CA: Germ cell nuclear factor is a repressor of CRIPTO-1 and CRIPTO-3. J Biol Chem 2006, 281:33497-33504
64. Dono R, Scalera L, Pacifico F, Acampora D, Persico MG, Simeone A: The murine cripto gene: expression during mesoderm induction and early heart morphogenesis. Development 1993, 118: $1157-1168$

65. Clarke CL, Roman SD, Graham J, Koga M, Sutherland RL: Progesterone receptor regulation by retinoic acid in the human breast cancer cell line T-47D. J Biol Chem 1990, 265:12694-12700

66. Clarke CL, Graham J, Roman SD, Sutherland RL: Direct transcriptional regulation of the progesterone receptor by retinoic acid diminishes progestin responsiveness in the breast cancer cell line T-47D. J Biol Chem 1991, 266:18969-18975

67. Savouret JF, Rauch M, Redeuilh G, Sar S, Chauchereau A, Woodruff K, Parker MG, Milgrom E: Interplay between estrogens, progestins, retinoic acid and AP-1 on a single regulatory site in the progesterone receptor gene. J Biol Chem 1994, 269: 28955-28962

68. Virgo BB, Bellward GD: Serum progesterone levels in the pregnant and postpartum laboratory mouse. Endocrinology 1974, 95: $1486-1490$

69. Mukherjee A, Soyal SM, Li J, Ying Y, He B, DeMayo FJ, Lydon JP: Targeting RANKL to a specific subset of murine mammary epithelial cells induces ordered branching morphogenesis and alveologenesis in the absence of progesterone receptor expression. FASEB J 2010, 24: 4408-4419

70. Anderson SM, Rudolph MC, McManaman JL, Neville MC: Key stages in mammary gland development-secretory activation in the mammary gland: it's not just about milk protein synthesis! Breast Cancer Res 2007, 9:204

71. Gonzalez-Suarez E, Jacob AP, Jones J, Miller R, Roudier-Meyer MP, Erwert R, Pinkas J, Branstetter D, Dougall WC: RANK ligand mediates progestin-induced mammary epithelial proliferation and carcinogenesis. Nature 2010, 468:103-107

72. Tanos T, Sflomos G, Echeverria PC, Ayyanan A, Gutierrez M, Delaloye JF, Raffoul W, Fiche M, Dougall W, Schneider P, YalcinOzuysal O, Brisken C: Progesterone/RANKL is a major regulatory axis in the human breast. Sci Transl Med 2013, 5:182ra155

73. Lydon JP, Ge G, Kittrell FS, Medina D, O’Malley BW: Murine mammary gland carcinogenesis is critically dependent on progesterone receptor function. Cancer Res 1999, 59:4276-4284

74. Visvader JE, Stingl J: Mammary stem cells and the differentiation hierarchy: current status and perspectives. Genes Dev 2014, 28: $1143-1158$

75. Rajaram RD, Buric D, Caikovski M, Ayyanan A, Rougemont J, Shan J, Vainio SJ, Yalcin-Ozuysal O, Brisken C: Progesterone and Wnt4 control mammary stem cells via myoepithelial crosstalk. EMBO J 2015, 34:641-652

76. Hamada S, Watanabe K, Hirota M, Bianco C, Strizzi L, Mancino M, Gonzales M, Salomon DS: beta-Catenin/TCF/LEF regulate expression of the short form human Cripto-1. Biochem Biophys Res Commun 2007, 355:240-244

77. Morkel M, Huelsken J, Wakamiya M, Ding J, van de Wetering M, Clevers H, Taketo MM, Behringer RR, Shen MM, Birchmeier W: Beta-catenin regulates Cripto- and Wnt3-dependent gene expression programs in mouse axis and mesoderm formation. Development 2003, 130:6283-6294

78. Nagaoka T, Karasawa H, Turbyville T, Rangel MC, Castro NP, Gonzales M, Baker A, Seno M, Lockett S, Greer YE, Rubin JS, Salomon DS, Bianco C: Cripto-1 enhances the canonical Wnt/betacatenin signaling pathway by binding to LRP5 and LRP6 co-receptors. Cell Signal 2013, 25:178-189 